FINANCIAL GLOBALIZATION, GROWTH AND VOLATILITY IN DEVELOPING COUNTRIES

\author{
Eswar Prasad \\ Kenneth Rogoff \\ Shang-Jin Wei \\ M. Ayhan Kose
}

Working Paper 10942 
NBER WORKING PAPER SERIES

\title{
FINANCIAL GLOBALIZATION, GROWTH AND VOLATILITY IN DEVELOPING COUNTRIES
}

\author{
Eswar Prasad \\ Kenneth Rogoff \\ Shang-Jin Wei \\ M. Ayhan Kose \\ Working Paper 10942 \\ http://www.nber.org/papers/w10942
}

\section{NATIONAL BUREAU OF ECONOMIC RESEARCH \\ 1050 Massachusetts Avenue \\ Cambridge, MA 02138}

December 2004

\begin{abstract}
An earlier version of this paper was presented at the NBER Globalization and Poverty Conference, September 10-12, 2004. We would like to thank Ann Harrison, Susan Collins, and the conference participants for their helpful suggestions. This paper is based on our earlier paper, entitled The Effects of Financial Globalization on Developing Countries: Some Empirical Evidence, International Monetary Fund Occasional Paper 220, 2003. This paper should not be reported as representing the views of the IMF or the NBER.The views expressed herein are those of the author(s) and do not necessarily reflect the views of the National Bureau of Economic Research.

(C) 2004 by Eswar Prasad, Kenneth Rogoff, Shang-Jin Wei, and M. Ayhan Kose. All rights reserved. Short sections of text, not to exceed two paragraphs, may be quoted without explicit permission provided that full credit, including (C) notice, is given to the source.
\end{abstract}


Financial Globalization, Growth and Volatility in Developing Countries

Eswar Prasad, Kenneth Rogoff, Shang-Jin Wei, and M. Ayhan Kose

NBER Working Paper No. 10942

December 2004

JEL No. F15, F36, F41, F43

\begin{abstract}
This paper provides a comprehensive assessment of empirical evidence about the impact of financial globalization on growth and volatility in developing countries. The results suggest that it is difficult to establish a robust causal relationship between financial integration and economic growth. Furthermore, there is little evidence that developing countries have been consistently successful in using financial integration to stabilize fluctuations in consumption growth. However, we do find that financial globalization can be beneficial under the right circumstances. Empirically, good institutions and quality of governance are crucial in helping developing countries derive the benefits of globalization. Similarly, macroeconomic stability appears to be an important prerequisite for ensuring that financial globalization is beneficial for developing countries. Finally, countries that employ relatively flexible exchange rate regimes and succeed in maintaining fiscal discipline are more likely to enjoy the potential growth and stabilization benefits of financial globalization.

Eswar S. Prasad

International Monetary Fund

19th Street, NW

Washington, DC 20433

eprasad@imf.org

Kenneth S. Rogoff

Economics Department

Harvard University

Littauer Center 232

Cambridge, MA 02138-3001

and NBER

krogoff@harvard.edu

Shang-Jin Wei

International Monetary Fund

Room 10-700

19th Street, NW

Washington, DC 20433

and NBER

swei@imf.org

M. Ayhan Kose

International Monetary Fund

19th Street, NW

Washington, DC 20433

akose@imf.org
\end{abstract}




\section{INTRODUCTION AND OVERVIEW}

The recent wave of financial globalization since the mid-1980s has been marked by a surge in capital flows among industrial countries and, more notably, between industrial and developing countries. While these capital flows have been associated with high growth rates in some developing countries, a number of countries have experienced episodic collapses in growth rates and significant financial crises over the same period, crises that have exacted a serious toll in terms of macroeconomic and social costs. As a result, an intense debate has emerged in both academic and policy circles about the effects of financial integration on developing economies. But much of the debate has been based on only casual and limited empirical evidence.

The objective of this paper is to provide an assessment of empirical evidence on the effects of financial globalization for developing economies. The paper will focus on a couple of related questions: (i) does financial globalization promote economic growth in developing countries? (ii) what is its impact on macroeconomic volatility in these countries?

While this paper does not deal directly with poverty issues, its main subject - the effects of financial globalization on economic growth and volatility - has important indirect effects. First, economic growth has been the most reliable source of poverty reduction. Second, holding level of income constant, an increase in volatility reduces the well-being of most households, especially those of the poor as they are least able to protect themselves.

The principal conclusions that emerge from the analysis are sobering, but in many ways informative from a policy perspective. It is true that many developing economies with a high degree of financial integration have also experienced higher growth rates. It is also true that, in theory, there are many channels by which financial openness could enhance growth. However, a systematic examination of the evidence suggests that it is difficult to establish a robust causal relationship between the degree of financial integration and output growth performance. Furthermore, from the perspective of macroeconomic stability, consumption is regarded as a better measure of well-being than output; fluctuations in consumption are therefore regarded as having a negative impact on economic welfare. There is little evidence that financial integration has helped developing countries to better stabilize fluctuations in consumption growth, notwithstanding the theoretically large benefits that could accrue to developing countries in this respect. In fact, new evidence presented in this paper suggests that low to moderate levels of financial integration may have made some countries subject to even greater volatility of consumption relative to that of output. Thus, while there is no proof in the data that financial globalization has benefited growth, there is evidence that some developing countries may have experienced greater consumption volatility as a result.

One must be careful, however, not to draw the inference from these results that financial globalization is inherently too risky, and that developing countries should retreat into stronger forms of capital controls. First, as we analyze in an earlier extended version of this paper (Prasad, Rogoff, Wei and Kose, 2003), empirical evidence supports the view that countries are considerably more likely to benefit from financial globalization when they take simultaneous 
steps-- sometimes even modest ones--to improve governance, transparency and financial sector regulation. Second, it is almost surely the case that excessive reliance on fixed exchange rate regimes has been a major contributory factor to financial crises in emerging market countries over the past fifteen years. Moving to more flexible exchange rate regimes is therefore likely to considerably alleviate some of the risks countries must endure as they become more financially globalized (for countries that are not financially globalized, fixed exchange rate regimes may be a perfectly good choice, as the empirical results in Rogoff et. al. 2004, suggest). Third, countries that consistently face problems associated with government debt (referred to as "serial defaulters" by Reinhart and Rogoff, 2004b), are more likely to benefit from financial globalization if their governments simultaneously take measures to avoid an excessive buildup of debt.

It is also important to note that much of the analysis in this paper focuses on de facto rather than de jure financial globalization. This makes sense in an empirical paper since capital controls come in so many flavors, and enforcement varies so widely across countries, that crosscountry empirical comparisons based on measures of de jure capital controls are extremely difficult to interpret. By contrast, de facto financial integration is not a variable that a country's government can easily regulate. Although many countries have tight capital controls on paper, their degree of de facto financial globalization is nevertheless high because these controls can be easily evaded in practice. This problem is almost surely exacerbated by the kind of domestic financial liberalizations that many countries have chosen to undergo over the past two decades in an effort to channel savings more efficiently and thereby spur growth. At the same time, some poor countries have few impediments to capital flows, but their level of de facto financial globalization is still very low, even when measured relative to national income.

This paper does not look directly at how financial globalization affects absolute or relative measures of poverty. The effects could easily go in opposite directions. On the one hand, sustained high growth is the most consistently successful policy for alleviating absolute poverty, as China and India have succeeded in doing over the past two decades. On the other hand, periods of high growth are often associated with higher income inequality and, therefore, relative measures of poverty may easily rise. Increased macroeconomic volatility, however, probably increases both absolute and relative measures of poverty, particularly in the case of financial crises that lead to sharp rises in unemployment. The evidence presented in this paper suggests that a detailed study of the link between financial globalization and poverty is likely to yield ambiguous results for emerging market countries, albeit with the same caveats: Countries that work simultaneously to improve institutions, and ones that avoid overly fixed exchange rate regimes, have a much better chance of seeing financial globalization lead to poverty reduction, at least by absolute measures.

The remainder of this section provides an overview of the structure of the paper. In brief, Section II begins with a documentation of some salient features of global financial integration from the perspective of developing countries. Sections III and IV analyze the evidence on the effects of financial globalization on growth and volatility, respectively, in developing countries. Section V concludes. 


\section{A. Definitions and Basic Stylized Facts}

Financial globalization and financial integration are, in principle different concepts. Financial globalization is an aggregate concept that refers to rising global linkages through crossborder financial flows. Financial integration refers to an individual country's linkages to international capital markets. Clearly, these concepts are closely related. For instance, increasing financial globalization is perforce associated with rising financial integration on average. In this paper, the two terms are used interchangeably.

Of more relevance for the purposes of this paper is the distinction between de jure financial integration, which is associated with policies on capital account liberalization, and actual capital flows. For example, indicator measures of the extent of government restrictions on capital flows across national borders have been used extensively in the literature. By this measure, many countries in Latin America would be considered closed to financial flows. On the other hand, the volume of capital actually crossing the borders of these countries has been large relative to the average volume of flows across all developing countries. Therefore, on a de facto basis, these countries are quite open to global financial flows. By contrast, some countries in Africa have few formal restrictions on capital account transactions but have not experienced significant capital flows. The analysis in this paper will focus largely on de facto measures of financial integration, as it is virtually impossible to compare the efficacy of various complex restrictions across countries. In the end, what matters most is the actual degree of openness. However, the paper will also consider the relationship between de jure and de facto measures.

As discussed in section II, a few salient features of global capital flows are relevant for the central themes of the paper. First, the volume of cross-border capital flows has risen substantially in the last decade. Not only has there been a much greater volume of flows among industrial countries but there has also been a surge in flows between industrial and developing countries. Second, this surge in international capital flows to developing countries is the outcome of both "pull" and "push" factors. "Pull factors" arise from changes in policies and other aspects of opening up by developing countries. These include liberalization of capital accounts and domestic stock markets, and large-scale privatization programs. "Push factors" include business cycle conditions and macroeconomic policy changes in industrial countries. From a longer-term perspective, this latter set of factors includes the rise in the importance of institutional investors in industrial countries and demographic changes (e.g., relative aging of the population in industrial countries). The importance of these factors suggests that, notwithstanding temporary interruptions in crisis periods or during global business cycle downturns, the past twenty years have been characterized by secular pressures for rising global capital flows to the developing world.

Another important feature of international capital flows is that the components of these flows differ markedly in terms of volatility. In particular, bank borrowing and portfolio flows are substantially more volatile than foreign direct investment. In spite of a caveat that accurate classification of capital flows is not easy, evidence suggests that the composition of capital flows can have a significant influence on a country's vulnerability to financial crises. 


\section{B. Does Financial Globalization Promote Growth in Developing Countries?}

Section III will summarize the theoretical benefits of financial globalization for economic growth and then review the empirical evidence. Financial globalization could, in principle, help to raise the growth rate in developing countries through a number of channels. Some of these directly affect the determinants of economic growth (augmentation of domestic savings, reduction in the cost of capital, transfer of technology from advanced to developing countries, and development of domestic financial sectors). Indirect channels, which in some cases could be even more important than the direct ones, include increased production specialization due to better risk management, and improvements in both macroeconomic policies and institutions induced by the competitive pressures or the "discipline effect" of globalization.

How much of the advertised benefits for economic growth have actually materialized in the developing world? As documented in this paper, the average income per capita for the group of more financially open (developing) economies does grow at a more favorable rate than that of the group of less financially open economies. However, whether this actually reflects a causal relationship and whether this correlation is robust to controlling for other factors remain unresolved questions. The literature on this subject, voluminous as it is, does not present a conclusive picture. A few papers find a positive effect of financial integration on growth. However, the majority find no effect or at best a mixed effect. Thus, an objective reading of the vast research effort to date suggests that there is no strong, robust and uniform support for the theoretical argument that financial globalization per se delivers a higher rate of economic growth.

Perhaps this is not surprising. As noted by several authors, most of the cross-country differences in per capita incomes stem not from differences in the capital-labor ratio, but from differences in total factor productivity, which could be explained by "soft" factors like governance and rule of law. In this case, while embracing financial globalization may result in higher capital inflows, it is unlikely to cause faster growth by itself. In addition, some of the countries with capital account liberalization have experienced output collapses related to costly banking or currency crises. This is elaborated below. An alternative possibility, as noted earlier, is that financial globalization fosters better institutions and domestic policies but that these indirect channels can not be captured in standard regression frameworks.

In short, while financial globalization can, in theory, help to promote economic growth through various channels, there is as yet no robust empirical evidence that this causal relationship is quantitatively very important. This points to an interesting contrast between financial openness and trade openness, since an overwhelming majority of research papers have found a positive effect of the latter on economic growth.

\section{What Is the Impact of Financial Globalization on Macroeconomic Volatility?}

In theory, financial globalization can help developing countries to better manage output and consumption volatility. Indeed, a variety of theories implies that the volatility of consumption relative to that of output should go down as the degree of financial integration increases; the essence of global financial diversification is that a country is able to offload some 
of its income risk in world markets. Since most developing countries are rather specialized in their output and factor endowment structures, they can, in theory, obtain even bigger gains than developed countries through international consumption risk sharing, that is, by effectively selling off a stake in their domestic output in return for a stake in global output.

How much of the potential benefits in terms of better management of consumption volatility has actually been realized? This question is particularly relevant in terms of understanding whether, despite the output volatility experienced by developing countries that have undergone financial crises, financial integration has protected them from consumption volatility. New research presented in section IV paints a troubling picture. Specifically, while the volatility of output growth has, on average, declined in the 1990s relative to the three earlier decades, the volatility of consumption growth relative to that of income growth has on average increased for the emerging market economies in the 1990s, which was precisely the period of a rapid increase in financial globalization. In other words, as argued in more detail later in the paper, procyclical access to international capital markets appears to have had a perverse effect on the relative volatility of consumption for financially integrated developing economies.

Interestingly, a more nuanced look at the data suggests the possible presence of a threshold effect. At low levels of financial integration, an increment in financial integration is associated with an increase in the relative volatility of consumption. However, once the level of financial integration crosses a threshold, the association becomes negative. In other words, for countries that are sufficiently open financially, relative consumption volatility starts to decline. This finding is potentially consistent with the view that international financial integration can help to promote domestic financial sector development, which in turn can help to moderate domestic macroeconomic volatility. However, thus far these benefits of financial integration appear to have accrued primarily to industrial countries.

In this vein, the proliferation of financial and currency crises among developing economies is often viewed as a natural consequence of the "growing pains" associated with financial globalization. These can take various forms. First, international investors have a tendency to engage in momentum trading and herding, which can be destabilizing for developing economies. Second, international investors may (together with domestic residents) engage in speculative attacks on developing countries currencies, thereby causing instability that is not warranted based on the economic and policy fundamentals of these countries. Third, the risk of contagion presents a major threat to otherwise healthy countries since international investors could withdraw capital from these countries for reasons unrelated to domestic factors. Fourth, a government, even if democratically elected, may not give sufficient weight to the interest of future generations. This becomes a problem when the interests of future and current generations diverge, causing the government to incur excessive amounts of debt. Financial globalization, by making it easier for governments to incur debt, might aggravate this "over-borrowing" problem. These four hypotheses are not necessarily independent, and can reinforce each other.

There is some empirical support for these hypothesized effects. For example, there is evidence that international investors do engage in herding and momentum trading in emerging markets, more so than in developed countries. Recent research also suggests the presence of 
contagion in international financial markets. In addition, some developing countries that open their capital markets do appear to accumulate unsustainably high levels of external debt.

To summarize, one of the theoretical benefits of financial globalization, other than to enhance growth, is to allow developing countries to better manage macroeconomic volatility, especially by reducing consumption volatility relative to output volatility. The evidence suggests that, instead, countries that are in the early stages of financial integration have been exposed to significant risks in terms of higher volatility of both output and consumption.

\section{The Role of Institutions and Governance in the Effects of Globalization}

While it is difficult to find a simple relationship between financial globalization and growth or consumption volatility, there is some evidence of nonlinearities or threshold effects in the relationship. That is, financial globalization, in combination with good macroeconomic policies and good domestic governance, appears to be conducive to growth (see Prasad et. al., 2003). For example, countries with good human capital and governance tend to do better at attracting foreign direct investment (FDI), which is especially conducive to growth. More specifically, recent research shows that corruption has a strongly negative effect on FDI inflows. Similarly, transparency of government operations, which is another dimension of good governance, has a strong positive effect on investment inflows from international mutual funds.

The vulnerability of a developing country to the "risk factors" associated with financial globalization is also not independent from the quality of macroeconomic policies and domestic governance. For example, research has demonstrated that an overvalued exchange rate and an overextended domestic lending boom often precede a currency crisis. In addition, lack of transparency has been shown to be associated with more herding behavior by international investors that can destabilize a developing country's financial markets. Finally, evidence shows that a high degree of corruption may affect the composition of a country's capital inflows in a manner that makes it more vulnerable to the risks of speculative attacks and contagion effects.

Thus, the ability of a developing country to derive benefits from financial globalization and its relative vulnerability to the volatility of international capital flows can be significantly affected by the quality of both its macroeconomic framework and institutions.

\section{E. Summary}

The objective of the paper is not so much to derive new policy propositions as it is to inform the debate on the potential and actual benefit-risk tradeoffs associated with financial globalization by reviewing the available empirical evidence and country experiences. The main conclusions are that, so far, it has proven difficult to find robust evidence in support of the proposition that financial integration helps developing countries to improve growth and to reduce macroeconomic volatility.

Of course, the absence of robust evidence on these dimensions does not necessarily mean that financial globalization has no benefits and carries only great risks. Indeed, most countries that have initiated financial integration have continued along this path, despite temporary 
setbacks. This observation is consistent with the notion that the indirect benefits of financial integration, which may be difficult to pick up in regression analysis, could be quite important. Also, the long run gains, in some cases yet unrealized, may far offset the short term costs. For instance, the European Monetary Union experienced severe and costly crises in the early 1990s as part of the transition to a single currency throughout much of Europe today.

While it is difficult to distill new and innovative policy messages from the review of the evidence, there appears to be empirical support for some general propositions. Empirically, good institutions and quality of governance are important not only in their own right, but in helping developing countries derive the benefits of globalization. Similarly, macroeconomic stability appears to be an important prerequisite for ensuring that financial integration is beneficial for developing countries. These points may already be generally accepted; the contribution of this paper is to show that there is some systematic empirical evidence to support them. In addition, the analysis suggests that financial globalization should be approached cautiously and with good institutions and macroeconomic frameworks viewed as preconditions.

\section{BASIC Stylized FACTS}

De jure restrictions on capital flows and actual capital flows across national borders are two ways of measuring the extent of a country's financial integration with the global economy. The differences between these two measures are important for understanding the effects of financial integration. By either measure, developing countries' financial linkages with the global economy have risen in recent years. ${ }^{l}$ However, a relatively small group of developing countries has garnered a lion's share of private capital flows from industrial to developing countries, which surged in the 1990s. Structural factors, including demographic shifts in industrial countries, are likely to provide an impetus to these "North-South" flows over the medium and long term.

\section{A. Measuring Financial Integration}

Capital account liberalization is typically considered an important precursor to financial integration. Most formal empirical work analyzing the effects of capital account liberalization has used a measure based on the official restrictions on capital flows as reported to the IMF by national authorities. However, this binary indicator directly measures capital controls but does not capture differences in the intensity of these controls. ${ }^{2}$ A more direct measure of financial openness is based on the estimated gross stocks of foreign assets and liabilities as a share of GDP. The stock data constitutes a better indication of integration, for our purposes, than the

\footnotetext{
${ }^{1}$ Eichengreen and Bordo (2002), Obtfeld and Taylor (2002), and Mauro, Sussman, and Yafeh (2002) examine historical roots of international financial integration.

${ }^{2}$ The restriction measure is available until 1995, when a new and more refined measure-not backward compatible_-was introduced. The earlier data were extended through 1998 by Mody and Murshid (2002).
} 
underlying flows since they are less volatile from year to year and are less prone to measurement error (assuming that such errors are not correlated over time). ${ }^{3,4}$

While these two measures of financial integration are related, they denote two distinct aspects. The capital account restrictions measure reflects the existence of de jure restrictions on capital flows while the financial openness measure captures de facto financial integration in terms of realized capital flows. This distinction is of considerable importance for the analysis in this paper and implies a $2 \times 2$ set of combinations of these two aspects of integration. Many industrial countries have attained a high degree of financial integration in terms of both measures. Some developing countries with capital account restrictions have found these restrictions ineffective in controlling actual capital flows. Episodes of capital flight from some Latin American countries in the 1970s and 1980s are examples of such involuntary de facto financial integration in economies that are de jure closed to financial flows (i.e., integration without capital account liberalization). On the other hand, some countries in Africa have few capital account restrictions but have experienced only minimal levels of capital flows (i.e., liberalization without integration). ${ }^{5}$ And, of course, it is not difficult to find examples of countries with closed capital accounts that are also effectively closed in terms of capital flows.

How has financial integration evolved over time for different groups of countries based on alternative measures? ${ }^{6}$ By either measure, the difference in financial openness between industrial and developing countries is quite stark. Industrial economies have had an enormous increase in financial openness, particularly in the 1990s. While this measure also increased for developing economies in that decade, the level remains far below that of industrial economies.

For industrial countries, unweighted cross-country averages of the two measures are mirror images and jointly confirm that these countries have undergone rapid financial integration

\footnotetext{
${ }^{3}$ These stock data were constructed by Lane and Milesi-Ferretti (2001). Operationally, this measure involves calculating the gross levels of FDI and portfolio assets and liabilities via the accumulation of the corresponding inflows and outflows, and making relevant valuation adjustments. A similar measure using the same underlying stock data has been considered by Chanda (2000) and O'Donnell (2001).

${ }^{4}$ Other measures of capital market integration include saving-investment correlations and various interest parity conditions (Frankel, 1992). These measures are difficult to operationalize for the extended time period and large number of countries in the data sample for this paper.

${ }^{5}$ An analogy from the literature on international trade may be relevant here. Some countries, due to their remoteness from major world markets or other unfavorable geographical attributes, have low trade flows despite having minimal barriers to trade even after controlling for various other factors. Similarly, certain countries, due to their remoteness from major financial centers, in terms of either physical distance or historical relationships, may experience limited capital flows despite having relatively open capital accounts, (see Loungani, Mody, and Razin (2003)).

${ }^{6}$ The dataset used in this paper consists of 76 industrial and developing countries (except where otherwise indicated) and covers the period 1960-99. Given the long sample period, several countries currently defined as industrial (e.g., Korea and Singapore) are included in the developing country group. The following were excluded from the dataset: most of the Highly Indebted Poor Countries (which mostly receive official flows), the transition economies of Eastern Europe and the Former Soviet Union (due to lack of data), very small economies (population less than 1.5 million) and oil-exporting countries in the Middle East. See the Data Appendix for a list of countries and further details on the dataset.
} 
since the mid-1980s (Figure 1). ${ }^{7}$ For developing countries, the average restriction measure indicates that, after a period of liberalization in the 1970s, the trend toward openness reversed in the 1980s. Liberalization resumed in the early 1990s but at a slow pace. On the other hand, the average financial openness measure for these countries, based on actual flows, shows a modest increase in the 1980s, followed by a sharp rise in the 1990s. The increase in the financial openness measure for developing economies reflects a more rapid de facto integration than is captured by the relatively crude measure of capital account restrictions.

However, the effects of financial integration in terms of increased capital flows have been spread very unevenly across developing countries. ${ }^{8}$ For examining the extent of these disparities, it is useful to begin with a very coarse classification of the developing countries in the sample into two groups based on a ranking according to the average of the financial openness measure over the last four decades (as well as an assessment of other indicators of financial integration).

The first group, which comprises 22 countries, is henceforth labeled as the set of More Financially Integrated (MFI) countries and the latter, which includes 33 countries, as the Less Financially Integrated (LFI) countries. ${ }^{9}$ This distinction must be interpreted with some care at this stage. In particular, it is worth repeating that the criterion is a measure of de facto integration based on actual capital flows rather than a measure of the strength of policies designed to promote financial integration. Indeed, a few of the countries in the MFI group do have relatively closed capital accounts in a de jure sense. In general, as argued below, policy choices do determine the degree and nature of financial integration. Nevertheless, for the analysis in this paper, the degree of financial openness based on actual capital flows is a more relevant measure.

It should be noted that the main conclusions of this paper are not crucially dependent on the particulars of the classification of developing countries into the MFI and LFI groups. This classification is obviously a static one and does not account for differences across countries in the timing and degree of financial integration. It is used for some of the descriptive analysis presented below but only in order to illustrate the conclusions from the more detailed econometric studies that are surveyed in the paper. The areas where this classification yields results different from those obtained from more formal econometric analysis will be clearly highlighted in the paper. The regression results reported in this paper are based on the gross capital flows measure described earlier which does capture differences across countries and changes over time in the degree of financial integration.

Figure 2 shows that the vast majority of international private gross capital flows of developing countries, especially in the 1990s, are accounted for by the relatively small group of

\footnotetext{
${ }^{7}$ A particularly rapid decline in controls occurred during the 1980 s, when the members of the European Community, now the European Union, liberalized capital controls. A surge in cross-border capital flows followed.

${ }^{8}$ Ishii and others (2002) examine in detail the experiences of a number of developing countries.

${ }^{9}$ Not surprisingly, this classification results in a set of MFI economies that roughly correspond to those included in the MSCI emerging markets stock index. The main differences are that we drop the transition economies because of limited data availability and add Hong Kong SAR and Singapore.
} 
MFI economies. ${ }^{10}$ By contrast, private capital flows to and from the LFI economies have remained very small over the last decade and, for certain types of flows, have even fallen relative to the late 1970s.

\section{B. North-South Capital Flows}

One of the key features of global financial integration over the last decade has been the dramatic increase in net private capital flows from industrial countries (the "North") to developing countries (the "South"). Figure 3 breaks down the levels of these flows into the four main constituent categories. The main increase has been in terms of FDI and portfolio flows, while the relative importance of bank lending has declined somewhat. In fact, net bank lending turned negative for a few years during the time of the Asian crisis.

The bulk of the surge in net FDI flows from the advanced economies has gone to MFI economies, with only a small fraction going to LFI economies (Figure 3, lower panels). Net portfolio flows show a similar pattern, although both types of flows to MFI economies fell sharply following the Asian crisis and have remained relatively flat since then. LFI economies have been much more dependent on bank lending (and, although not shown here, on official flows including loans and grants). There were surges in bank lending to this group of countries in the late 1970s and early 1990s.

Another important feature of these flows is that they differ substantially in terms of volatility. Table 1 shows the volatility of FDI, portfolio flows and bank lending to developing economies. FDI flows are the least volatile of the different categories of private capital flows to developing economies, which is not surprising given their long-term and relatively fixed nature. Portfolio flows tend to be far more volatile and prone to abrupt reversals than FDI. These patterns hold when the MFI and LFI economies are examined separately. Even in the case of LFIs, the volatility of FDI flows is much lower than that of other types of flows. ${ }^{11}$ This difference in the relative volatility of different categories has important implications that will be examined in more detail later.

\section{Factors Underlying the Rise in North-South Capital Flows}

The surge in net private capital flows to MFIs, as well as the shifts in the composition of these flows, can be broken down into "pull" and "push" factors (Calvo, Leiderman, and Reinhart (1993)). These are related to, respectively, (i) policies and other developments in the MFIs and (ii) changes in global financial markets. The first category includes factors such as stock market

\footnotetext{
${ }^{10}$ Note that the scale of the upper graph is twice as big as the lower one.

${ }^{11}$ Consistent with these results, Taylor and Sarno (1999) find that FDI flows are more persistent than other types of flows. Hausmann and Fernandez-Arias (2000) find weaker confirmation of this result and also note that, although the volatility of FDI flows has been rising over time, it remains lower than that of other types of flows. In interpreting these results, there is a valid concern about potential misclassification of the different types of capital flows. Since most of the studies cited here use similar data sources, this is not a problem that can be easily resolved by examining the conclusions of multiple studies.
} 
liberalizations and privatization of state-owned companies that have stimulated foreign inflows. The second category includes the growing importance of depositary receipts and cross-listings and the emergence of institutional investors as key players driving international capital flows to emerging markets.

The investment opportunities afforded by stock market liberalizations, which have typically included the provision of access to foreign investors, have enhanced capital flows to MFIs. How much have restrictions on foreign investors' access to local stock markets in MFIs changed over time? To answer this question, it is useful to examine a new measure of stock market liberalization that captures restrictions on foreign ownership of domestic equities. This measure, constructed by Edison and Warnock (2001), is obviously just one component of capital controls, but an appropriate one for modeling equity flows. Figure 4 shows that stock market liberalizations in MFI economies in different regions have proceeded rapidly, in terms of both intensity and speed. ${ }^{12}$

Mergers and acquisitions, especially those resulting from the privatization of state-owned companies, were an important factor underlying the increase in FDI flows to MFIs during the 1990s. The easing of restrictions on foreign participation in the financial sector in MFIs has also provided a strong impetus to this factor. ${ }^{13}$

Institutional investors in the industrial countries-including mutual funds, pension funds, hedge funds, and insurance companies - have assumed an important role in channeling capital flows from industrial to developing economies. They have helped individual investors overcome the information and transaction cost barriers that previously limited portfolio allocations to emerging markets. Mutual funds, in particular, have served as an important instrument for individuals to diversify their portfolios into developing country holdings. ${ }^{14}$ Although international institutional investors devote only a small fraction of their portfolios to holdings in

\footnotetext{
${ }^{12}$ The stock market liberalization index is based on two indices constructed by the International Finance Corporation (IFC) for each country - the Global Index (IFCG) and the Investable Index (IFCI). The IFCG represents the full market while the IFCI represents the portion of the market available to foreign investors, where availability is determined by the IFC based on legal and liquidity criteria. Edison and Warnock (2001) propose using the ratio of the market capitalization of the IFCG to that of the IFCI as a measure of stock market liberalization. This ratio provides a quantitative measure of the degree of access that foreign investors have to a particular country's equity markets; one minus this ratio can be interpreted a measure of the intensity of capital controls in this dimension.

${ }^{13}$ The World Bank's Global Development Finance Report 2001 notes that FDI in Latin America's financial sector has come about through the purchases of privately-owned domestic banks, driving up the share of banking assets under foreign control from 8 percent in 1994 to 25 percent in 1999. In East Asia, foreign investors have purchased local banks in financial distress, leading to an increase in the share of banking assets under foreign control from 2 percent in 1994 to 6 percent in 1999.

${ }^{14}$ The presence of mutual funds in MFIs has grown substantially during the 1990s. For example, dedicated emerging market equity funds held $\$ 21$ billion in Latin American stocks by end-1995. By end-1997, their holdings had increased to $\$ 40$ billion. While mutual funds' growth in Asia has been less pronounced, the presence of mutual funds is still important in many countries in that region. See Eichengreen and Mathieson (1998) for a detailed study on hedge funds.
} 
MFIs, they have an important presence in these economies, given the relatively small size of their capital markets. Funds dedicated to emerging markets alone hold on average 5-15 percent of the Asian, Latin American, and transition economies' market capitalization.

Notwithstanding the moderation of North-South capital flows following recent emerging market crises, certain structural forces are likely to lead to a revival of these flows over the medium and long term. Demographic shifts, in particular, constitute an important driving force for these flows. Projected increases in old-age dependency ratios reflect the major changes in demographic profiles that are underway in industrial countries. This trend is likely to intensify further in the coming decades, fueled both by advances in medical technology that have increased average life spans and the decline in fertility rates. Financing the post-retirement consumption needs of a rapidly aging population will require increases in current saving rates, both national and private, in these economies. However, if such increases in saving rates do materialize, they are likely to result in a declining rate of return on capital in advanced economies, especially relative to that in the capital-poor countries of the South. This will lead to natural tendencies for capital to flow to countries where it has a potentially higher return.

All of these forces imply that, despite the recent sharp reversals in North-South capital flows, developing countries will eventually once again face the delicate balance of opportunities and risks afforded by financial globalization. Are the benefits derived from financial integration sufficient to offset the costs of increased exposure to the vagaries of international capital flows? The paper now turns to an examination of the evidence on this question.

\section{FINANCIAL INTEGRATION AND ECONOMIC GROWTH}

Theoretical models have identified a number of channels through which international financial integration can help to promote economic growth in the developing world. However, it has proven difficult to empirically identify a strong and robust causal relationship between financial integration and growth.

\section{A. Potential Benefits of Financial Globalization in Theory}

In theory, there are a number of direct and indirect channels through which embracing financial globalization can help enhance growth in developing countries. Figure 5 provides a schematic summary of these possible channels. These channels are inter-related in some ways, but this delineation is useful for reviewing the empirical evidence on the quantitative importance of each channel. ${ }^{15}$

\footnotetext{
${ }^{15}$ Some of these channels are also in play in transmitting the beneficial effects of globalization to the poor. For example, augmentation of domestic savings, reduction in the cost of capital, transfer of technological know-how, and stimulation of domestic financial sector development could all provide direct growth benefits which in turn help reduce poverty. Agenor (2003), Easterly (2004) and Goldberg and Pavcnik (2004) discuss various theoretical channels through which globalization affects poverty.
} 


\section{Direct Channels}

\section{Augmentation of domestic savings}

North-South capital flows in principle benefit both groups. They allow for increased investment in capital-poor countries while they provide a higher return on capital than is available in capital-rich countries. This effectively reduces the risk-free rate in the developing countries.

\section{Reduction in the cost of capital through better global allocation of risk}

International asset pricing models predict that stock market liberalization improves the allocation of risk (Henry (2000), and Stulz (1999a,b)). First, increased risk sharing opportunities between foreign and domestic investors might help to diversify risks. This ability to diversify in turn encourages firms to take on more total investment, thereby enhancing growth. Third, as capital flows increase, the domestic stock market becomes more liquid, which could further reduce the equity risk premium, thereby lowering the cost of raising capital for investment.

\section{Transfer of technological and managerial know-how}

Financially integrated economies seem to attract a disproportionately large share of FDI inflows, which have the potential to generate technology spillovers and to serve as a conduit for passing on better management practices. These spillovers can raise aggregate productivity and, in turn, boost economic growth (Borensztein, De Gregorio, and Lee (1998), and Grossman and Helpman (1991a, 1991b)).

\section{Stimulation of domestic financial sector development}

It has already been noted that international portfolio flows can increase the liquidity of domestic stock markets. Increased foreign ownership of domestic banks can also generate a variety of other benefits (Levine (1996); Caprio and Honohan (1999)). First, foreign bank participation can facilitate access to international financial markets. Second, it can help improve the regulatory and supervisory framework of the domestic banking industry. Third, foreign banks often introduce a variety of new financial instruments and techniques and also foster technological improvements in domestic markets. The entry of foreign banks tends to increase competition which, in turn, can improve the quality of domestic financial services as well as allocative efficiency.

\section{Indirect Channels}

\section{Promotion of specialization}

The notion that specialization in production may increase productivity and growth is intuitive. However, without any mechanism for risk management, a highly specialized 
production structure will produce high output volatility and, hence, high consumption volatility. Concerns about exposure to such increases in volatility may discourage countries from taking up growth-enhancing specialization activities; the higher volatility will also generally imply lower overall savings and investment rates. In principle, financial globalization could play a useful role by helping countries to engage in international risk sharing and thereby reduce consumption volatility. This point will be taken up again in the next section. Here, it should just be noted that risk sharing would indirectly encourage specialization, which in turn would raise the growth rate. This logic is explained by Brainard and Cooper (1968), Kemp and Liviatan (1973), Ruffin (1974), and Imbs and Wacziarg (2003). Among developed countries and across regions within given developed countries, there is indeed some evidence that better risk sharing is associated with higher specialization (Kalemi-Ozcan, Sorensen, and Yosha (2001)).

\section{Commitment to better economic policies}

International financial integration could increase productivity in an economy through its impact on the government's ability to credibly commit to a future course of policies. More specifically, the disciplining role of financial integration could change the dynamics of domestic investment in an economy to the extent that it leads to a reallocation of capital towards more productive activities in response to changes in macroeconomic policies. National governments are occasionally tempted to institute predatory tax policies on physical capital. The prospect of such policies tends to discourage investment and reduce growth. Financial opening can be selfsustaining and constrains the government from engaging in such predatory policies in the future since the negative consequences of such actions are far more severe under financial integration. Gourinchas and Jeanne (2003) illustrate this point in a theoretical model.

\section{Signaling}

A country's willingness to undertake financial integration could be interpreted as a signal that it is going to practice more friendly policies towards foreign investment in the future. Bartolini and Drazen (1997a) suggest that the removal of restrictions on capital outflows can, though its signaling role, lead to an increase in capital inflows. Many countries, including Colombia, Egypt, Italy, New Zealand, Mexico, Spain, Uruguay, and the United Kingdom have received significant capital inflows after removing restrictions on capital outflows. ${ }^{16}$

\section{B. Empirical Evidence}

On the surface, there seems to be a positive association between embracing financial globalization and the level of economic development. Industrial countries in general are more financially integrated with the global economy than developing countries. So embracing globalization is apparently part of being economically advanced.

Within the developing world, it is also the case that more financially integrated (MFI) economies grew faster than less financially integrated (LFI) economies over the last three

\footnotetext{
${ }^{16}$ See Mathieson and Rojas-Suarez (1993) and Labán and Larrain (1997).
} 
decades. From 1970 to 1999, average output per capita rose almost threefold in the group of MFI developing economies, almost six times greater than the corresponding increase for LFI economies. This pattern of higher growth for the former group applies over each of the three decades and also to consumption and investment growth.

However, there are two problems with concluding a positive effect of financial integration on growth from this data pattern. First, this pattern may be fragile upon closer scrutiny. Second, these observations only reflect an association between international financial integration and economic performance rather than necessarily a causal relationship. In other words, these observations do not rule out the possibility that there is reverse causation: countries that manage to enjoy a robust growth may also choose to engage in financial integration even if financial globalization does not directly contribute to faster growth in a quantitatively significant way.

To obtain an intuitive impression of the relationship between financial openness and growth, Table 2 presents a list of the fastest growing developing economies during 1980-2000 and a list of the slowest growing (or fastest declining) economies during the same period. Some countries have undergone financial integration during this period, especially in the latter half of the 1990s. ${ }^{17}$ Therefore, any result based on total changes over this long period should be interpreted with caution. Nonetheless, several features of the table are noteworthy.

An obvious observation that can be made from the table is that financial integration is not a necessary condition for achieving a high growth rate. China and India have achieved high growth rates despite somewhat limited and selective capital account liberalization. For example, while China became substantially more open to foreign direct investment, it was not particularly open to most other types of cross-border capital flows. Mauritius and Botswana have managed to achieve very strong growth rates during the period, although they are relatively closed to financial flows.

The second observation that can be made is that financial integration is not a sufficient condition for a fast economic growth rate either. For example, Jordan and Peru had become relatively open to foreign capital flows during the period; yet, their economies suffered a decline rather than enjoying positive growth during the period. On the other hand, Table 2 also suggests that declining economies are more likely to be financially closed, though the direction of causality is not clear as explained before.

This way of looking at country cases with extreme growth performance is only informative up to a point; it needs to be supplemented by a comprehensive examination of the experience of a broader set of countries using a more systematic approach to measuring financial openness. To illustrate this relationship more broadly, Figure 6 presents a scatter plot of the growth rate of real per capita GDP against the increase in financial integration over 1982-97.

\footnotetext{
${ }^{17}$ Table 2 reports the growth rates of real per capita GDP in constant local currency units. The exact growth rates and country rankings may change if different measures such as per capita GDP in dollar terms or on a PPP basis are used.
} 
There is essentially no association between these variables. Figure 7 presents a scatter plot of these two variables after taking into account the effects of a country's initial income, initial schooling, average investment-to-GDP ratio, political instability and regional location. Again, the figure does not suggest a positive association between financial integration and economic growth. In fact, this finding is not unique to the particular choice of the time period or the country coverage as reflected in a broad survey of other research papers on the subject.

A number of empirical studies have tried to systematically examine whether financial integration contributes to growth using various approaches to dealing with the difficult problem of proving causation. Table 3 summarizes the 14 most recent studies on this subject. ${ }^{18}$ Three out of the fourteen papers report a positive effect of financial integration on growth. However, the majority of the papers tend to find no effect or a mixed effect for developing countries. This suggests that, if financial integration has a positive effect on growth, it is probably not strong or robust. ${ }^{19}$

Of the papers summarized in Table 3, the one by Edison, Levine, Ricci, and Sløk (2002) is perhaps the most thorough and comprehensive in terms of measures of financial integration and in terms of empirical specifications. These authors measure a country's degree of financial integration both by the government's restrictions on capital account transactions as recorded in the IMF's AREAER and by the observed size of capital flows crossing the border, normalized by the size of the economy. The data set in that paper goes through 2000, the latest year analyzed in any existing study on this subject. Furthermore, the authors also employ a statistical methodology that allows them to deal with possible reverse causality-i.e., the possibility that any observed association between financial integration and growth could result from the mechanism that faster growing economies also more likely to choose to liberalize their capital accounts. After a battery of statistical analyses, that paper concludes that, overall, there is no robustly significant effect of financial integration on economic growth.

\section{Synthesis}

Why is it so difficult to find a strong and robust effect of financial integration on economic growth for developing countries, when the theoretical basis for this result is apparently so strong? Perhaps there is some logic to this outcome after all. A number of researchers have now concluded that most of the differences in income per capita across countries stem not from differences in capital-labor ratios, but from differences in total factor productivity, which, in turn, could be explained by "soft" factors or "social infrastructure" like governance, rule of law,

\footnotetext{
${ }^{18}$ This extends the survey in World Economic Outlook, October 2001, and Edison, Klein, Ricci, and Sløk (2002).

${ }^{19}$ As discussed in Appendix I, there is some evidence that different types of capital flows may have different effects on growth. Recent research suggests that FDI flows are positively associated with domestic investment and output growth in a relatively consistent manner. For example, Bosworth and Collins (1999) find that while the impact of portfolio flows on investment growth is quite minor, there is a strong positive relationship between FDI flows and investment growth. In particular, their findings suggest that there exists an almost one-for-one relationship between FDI flows and domestic investment.
} 
and respect for property rights. ${ }^{20}$ In this case, while financial integration may open the door for additional capital to come in from abroad, it is unlikely to offer a major boost to growth by itself. In fact, if domestic governance is sufficiently weak, financial integration could cause an exodus of domestic capital and, hence, lower the growth rate of an economy.

This logic can be illustrated using the results reported in Senhadji (2000). Over the period 1960 to 1994, the average growth rate of per capita output for the group of countries in subSaharan Africa was the lowest among regional groupings of developing countries. The difference in physical and human capital accumulation is only part of the story for why growth rates differ across countries. The gap in total factor productivity is the major element in explaining the difference in the growth rates.

Another possible explanation for why it is difficult to detect a causal effect of financial integration on growth is the costly banking crises that some developing countries have experienced in the process of financial integration. The results in Kaminsky and Reinhart (1999) suggest that a flawed sequencing of domestic financial liberalization, when accompanied by capital account liberalization, increases the chance of domestic banking crises and/or exchange rate crises. These crises are often accompanied by output collapses. As a result, the benefits from financial integration may not be evident in the data. ${ }^{21}$

It is interesting to contrast the empirical literature on the effects of financial integration with that on the effects of trade integration. There is a large literature suggesting that openness to trade has a positive impact on growth (e.g., Sachs and Warner, 1995; Frankel and Romer, 1999; Dollar and Kraay, 2002; and Wacziarg and Welch, 2003), although some of the findings in this literature have been challenged by Rodriquez and Rodrik (2000), who raise questions about the measures of trade openness and the econometric methods employed in these studies. Nevertheless, an overwhelming majority of empirical papers employing various techniques, including country case studies as well as cross-country regressions, find that trade openness helps to promote economic growth. In a recent paper that surveys all the prominent empirical research on the subject, Berg and Krueger (2002) conclude that "[v]aried evidence supports the view that trade openness contributes greatly to growth." Furthermore, "[c]ross-country

\footnotetext{
${ }^{20}$ See Hall and Jones (1999), Senhadji (2000), Acemoglu, Johnson, and Robinson (2001), Easterly and Levine (2001), and Rogoff (2002) on the role of productivity difference in explaining cross-country difference in income. Gourinchas and Jeanne (2003) is the only paper that has made a direct comparision between gains from international financial integration and those from a rise in productivity. In a calibrated model, they show that the welfare gain from perfect financial integration is roughly equivalent to a one percent permanent increase in consumption for the typical non-OECD economy. By contrast, a productivity increase of the order of magnitude experienced in post-war Korea yields a welfare benefit that is more than one hundred times larger. The low gains from international financial integration comes from the fact that less developed countries are on average not very far from their potential level of capital. Non-OECD countries are less developed not primarily because they are capital-scarce, but because productivity is constrained by quality of institutions, economic policies and other factors.

${ }^{21}$ See Ishii et. al. (2002) for country cases in this regard.
} 
regressions of the level of income on various determinants generally show that openness is the most important policy variable."22

The differential effects between trade and financial integration are echoed in recent empirical research (see Appendix II). As an alternative to examining the effect on economic growth or level of income, one can examine the effects of trade and financial openness on a society's health status. Using data on 79 developing countries, Wei and Wu (2002a) report several pieces of evidence suggesting that a faster increase in trade openness-especially when measured by the reduction in tariff rates-is associated with a faster increase in life expectancy and a faster reduction in infant mortality, even after one takes into account the effect of income, institutions, and other factors. In contrast, higher financial integration is not associated with a faster improvement in a society's health status. This suggests that, in health dimension, as in the growth literature, it is harder to find a beneficial role for financial integration compared to trade integration for developing countries. ${ }^{23}$

In related research, Kose, Prasad, and Terrones (2004) analyze how trade and financial integration affect the relationship between growth and volatility. Running various regression models, first Ramey and Ramey (1995), then several other researchers (Martin and Rogers (2000), Fatas (2003) and Hnatkovska and Loayza (2003)), document that volatility and growth are negatively correlated. The results by Kose, Prasad, and Terrones (2004) suggest that trade and financial integration weaken the negative growth-volatility relationship. Specifically, in regressions of growth on volatility and other control variables, they find that the estimated coefficients on interactions between volatility and trade integration are significantly positive. In other words, countries that are more open to trade appear to face a less severe tradeoff between growth and volatility. They report a similar, although slightly less robust, result for the interaction of financial integration with volatility.

It is useful to note that there may be a complementary relationship between trade and financial openness. ${ }^{24}$ For example, if a country has severe trade barriers protecting some inefficient domestic industries, then capital inflows may end up being directed to those industries, thereby exacerbating the existing misallocation of resources. Thus, there is a concrete

\footnotetext{
${ }^{22}$ Baldwin (2003), Winters (2004) and Tang and Harrison (2004) also provide surveys of the literature on trade liberalization and economic growth. Winters (2004) concludes that "while there are serious methodological challenges and disagreements about the strength of the evidence, the most plausible conclusion is that liberalization generally induces a temporary (but possibly long-lived) increase in growth." Tang and Harrison (2004) argue that "while trade integration can strengthen an effective growth strategy, it cannot ensure its effectiveness. Other elements are needed, such as sound macroeconomic management, building trade-related infrastructure, and trade related institutions, economy-wide investments in human capital and infrastructure, or building strong institutions."

${ }^{23}$ The contrast between financial and trade openness may have important lessons for policies. While there appear to be relatively few prerequisites for deriving benefits from trade openness, obtaining benefits from financial integration requires several conditions to be in place (this is discussed in more detail in Prasad, Rogoff, Wei and Kose, 2003, Chapter V).

${ }^{24}$ This point is stressed in the September 2002 World Economic Outlook.
} 
channel through which financial openness without trade openness could lower a country's level of efficiency.

Of course, the lack of a strong and robust effect of financial integration on economic growth does not necessarily imply that theories that make this connection are wrong. One could argue that the theories are about the long-run effects, and most theories abstract from the nittygritty of institutional building, governance improvement, and other "soft" factors that are necessary ingredients for the hypothesized channels to take effect. Indeed, developing countries may have little choice but to strengthen their financial linkages eventually in order to improve their growth potential in the long run. The problem is how to manage the short-run risks apparently associated with financial globalization. Financial integration without a proper set of preconditions might lead to few growth benefits and more output and consumption volatility in the short run, a subject that is taken up in the next section.

Since growth and poverty reduction are intimately related, then the question of how financial globalization affects growth is closely linked to the question of how financial globalization affects poverty. The fact that the evidence on growth is indecisive almost surely implies that evidence on poverty reduction is as well. Recent research confirms this conclusion. For example, Easterly (2004) documents that neither financial nor trade flows have any significant impact on poverty. On the other hand, research by Dollar and Kraay $(2002,2004)$ suggests that increased trade flows could lead to higher economic growth which in turn could reduce poverty. Kraay (2004) provides strong evidence for the importance of economic growth in poverty reduction as his analysis shows that most of the variation in changes in poverty during the 1980s and 1990s is explained by growth in average income in developing countries. Agenor (2003) finds that there is a nonlinear relationship between globalization and poverty. His empirical results indicate that while globalization could reduce poverty in countries with a higher degree of economic integration, it could have an adverse impact on the income levels of the poor in countries with a lower degree of integration. ${ }^{25}$ This nonlinearity stems from the fact that globalization has a sizeable impact on the quality of institutions only beyond a certain level of trade and financial integration and institutions (including an efficient social safety net) play a major role in channeling the beneficial effects of globalization to the poor and shielding them from its costs.

Although there has been an intensive debate about the potentially adverse impact of globalization on income inequality, there is no clear empirical evidence that globalization has fostered a sharp rise in worldwide inequality. Several recent studies focus on the impact of globalization on income inequality across countries, these studies have yet to provide a conclusive answer. For example, globalization could accentuate the already substantial inequality of national incomes and, in particular, lead to stagnation of incomes and living standards in countries that do not participate in this process. Consistent with this view, Quah (1997) has documented that there is evidence in cross-country data of a "twin peaks" phenomenon whereby per capita incomes converge within each of two groups of countries (advanced countries and

\footnotetext{
${ }^{25}$ Agenor (2003) uses a weighted average of trade and financial openness indicators as a measure of economic integration.
} 
globalizers) while average incomes continue to diverge across these two groups of countries. In other words, advanced countries and globalizers converge in terms of per capita incomes and so do non-globalizers, but these two groups diverge from each other in terms of their average incomes. Sala-i-Martin (2002), on the other hand, argues that a more careful analysis, using individuals rather than countries as the units of analysis, shows that global inequality has declined during the recent wave of globalization.

By the same token, if the institutional preconditions for financial globalization to benefit growth are in place, then it is likely financial globalization will help to alleviate poverty as well.

\section{FinanCial Globalization AND MaCroeconomic Volatility}

International financial integration should, in principle, help countries to reduce macroeconomic volatility. The survey presented in this section, including some new evidence, suggests that developing countries, in particular, have not attained this potential benefit. The process of capital account liberalization has often been accompanied by increased vulnerability to crises. Globalization has heightened these risks since financial linkages have the potential of amplifying the effects of both real and financial shocks.

Holding growth constant, higher macroeconomic volatility would normally be associated with an increase in inequality of income, and therefore measures of poverty based on inequality. If the growth benefits are large - as indeed they may well be though the evidence is clearly very mixed - then of course, increased financial integration may increase relative poverty measures in the short run while reducing absolute (but not necessarily relative) poverty measures in the longer run. ${ }^{26}$

\section{A. Macroeconomic Volatility ${ }^{27}$}

One of the potential benefits of globalization is that it should provide better opportunities for reducing volatility by diversifying risks. Indeed, these benefits are presumably even greater for developing countries that are intrinsically subject to higher volatility on account of their being less diversified than industrial economies in terms of their production structures. However, recent crises in some MFIs suggest that financial integration may in fact have increased volatility.

What is the overall evidence of the effect of globalization on macroeconomic volatility? In addressing this question, it is important to make a distinction between output and consumption volatility. In theoretical models, the direct effects of global integration on output volatility are ambiguous. Financial integration provides access to capital that can help capital-poor developing countries to diversify their production base. On the other hand, rising financial integration could also lead to increasing specialization of production based on comparative advantage

\footnotetext{
${ }^{26}$ Mechanically, a rise in the volatility of consumption could lead to a decrease in the poverty head count. However, the increase in the volatility of consumption adversely affects the poor households' welfare.

${ }^{27}$ This subsection draws heavily on Kose, Prasad, and Terrones (2003a).
} 
considerations, thereby making economies more vulnerable to shocks that are specific to industries (Razin and Rose (1994)).

Irrespective of the effects on output volatility, theory suggests that financial integration should reduce consumption volatility. The ability to reduce fluctuations in consumption is regarded as an important determinant of economic welfare. Access to international financial markets provides better opportunities for countries to share macroeconomic risk and, thereby, smooth consumption. The basic idea here is that, since output fluctuations are not perfectly correlated across countries, trade in financial assets can be used to delink national consumption levels from the country-specific components of these output fluctuations (see Obstfeld and Rogoff (1998), Chapter 5). Appendix III provides a detailed analytical examination of this issue and shows that the gains from consumption smoothing are potentially very large for developing economies.

Notwithstanding the importance of this issue, the empirical evidence on the effects of globalization on macroeconomic volatility is rather sparse and, in particular, the evidence concerning the effects of financial integration on volatility is limited and inconclusive (see Appendix IV). In addition, the existing literature has largely been devoted to analyzing the effects of financial integration on output volatility, with little attention paid to consumption volatility. Hence, this paper now provides some new evidence on this topic.

Table 4 examines changes in volatility for different macroeconomic aggregates over the last four decades. Consistent with evidence presented in the September 2002 World Economic Outlook, MFI economies on average have lower output volatility than LFI economies.

Interestingly, there is a significant decline in average output volatility in the 1990s for both industrial and LFI economies but a far more modest decline for MFI economies. The picture is similar for a broader measure of income that includes factor income flows and terms of trade effects, which are particularly important for developing countries. Figure 8 (top panel), which shows the evolution of the average volatility of income growth for different groups of countries, confirms these results and shows that they are not sensitive to the decade-wise breakdown of the data, although there is a pick-up in volatility for MFIs towards the end of the sample. ${ }^{28}$

The third panel of this table shows that average consumption volatility in the 1990s has declined in line with output volatility for both industrial economies and LFI economies. By contrast, for MFI economies, the volatility of private consumption has in fact risen in the 1990s relative to the 1980 s for MFI economies. It is possible that looking at the volatility of private consumption is misleading as public consumption could be playing an important smoothing role, especially in developing economies. It is true, as shown in the fourth panel of Table 4, that total consumption is generally less volatile than private consumption. However, these results confirm the pattern that, on average, consumption volatility for industrial and LFI economies declined in the 1990s. By contrast, it increases for MFI economies over the same period. Figure 8 (lower panel), which shows the evolution of the average volatility of total consumption growth over a

\footnotetext{
${ }^{28}$ The figure shows the median standard deviation of income growth for each country group, based on standard deviations calculated for each country over a ten-year rolling window.
} 
ten-year rolling window, yields a similar picture. Could this simply be a consequence of higher income volatility for MFI economies?

Strikingly, for the group of MFI countries, the volatility of total consumption relative to that of income has actually increased in the 1990s relative to earlier periods. The bottom panel of Table 4 shows the median ratio of the volatility of total consumption growth to that of income growth for each group of countries. For MFI economies, this ratio increases from 0.76 in the 1980 s to 0.92 in the 1990 s, while it remains essentially unchanged for the other two groups of countries. Thus, the increase in the 1990s of the volatility of consumption relative to that of income for the MFI economies suggests that financial integration has not provided better consumption smoothing opportunities for these economies. ${ }^{29}$

More formal econometric evidence is presented by Kose, Prasad, and Terrones (2003a), who use measures of capital account restrictions as well as gross financial flows to capture different aspects of financial integration, as well as differences in the degree of integration across countries and over time. This analysis confirms the increase in the relative volatility of consumption for countries that have larger financial flows, even after controlling for macroeconomic variables as well as country characteristics such as trade openness and industrial structure. However, these authors also identify an important threshold effect-beyond a particular level, financial integration significantly reduces volatility. Most developing economies, including MFI economies, are unfortunately well below this threshold. ${ }^{30}$

Why has the relative volatility of consumption increased precisely in those developing countries that are more open to financial flows? One explanation is that positive productivity and output growth shocks during the late 1980s and early 1990s in these countries led to consumption booms that were willingly financed by international investors. These consumption booms were accentuated by the fact that many of these countries undertook domestic financial liberalization at the same time that they opened up to international financial flows, thereby loosening liquidity constraints at both the individual and national levels. When negative shocks hit these economies, however, they rapidly lost access to international capital markets. For the financial integration measure used in this paper, the threshold occurs at a ratio of about 50 percent of GDP. The countries in the sample that have a degree of financial integration above this threshold are all industrial countries.

Consistent with this explanation, a growing literature suggests that the procyclical nature of capital flows appears to have had an adverse impact on consumption volatility in developing economies. ${ }^{31}$ One manifestation of this procyclicality is the phenomenon of "sudden stops" of

\footnotetext{
${ }^{29}$ It should be noted that, despite the increase in the $1990 \mathrm{~s}$, the volatility of both private and total consumption for the MFI economies is, on average, still lower than for LFI economies.

${ }^{30}$ For the financial integration measure used in this paper, the threshold occurs at a ratio of about 50 percent of GDP. The countries in the sample that have a degree of financial integration above this threshold are all industrial countries.

${ }^{31}$ The notion of procylicality here is that capital inflows are positively correlated with domestic business cycle conditions in these countries.
} 
capital inflows (see Calvo and Reinhart (1999)). More generally, access to international capital markets has a procyclical element, which tends to generate higher output volatility as well as excess consumption volatility (relative to that of income). Reinhart (2002), for instance, finds that sovereign bond ratings are procyclical. Since the spreads on bonds of developing economies are strongly influenced by these ratings, this implies that costs of borrowing on international markets are procyclical as well. Kaminsky and Reinhart (2002) present more direct evidence on the procyclical behavior of capital inflows. ${ }^{32}$

\section{B. Crises as Special Cases of Volatility}

Crises can be regarded as particularly dramatic episodes of volatility. In fact, the proliferation of financial crises is often viewed as one of the defining aspects of the intensification of financial globalization over the last two decades. Furthermore, the fact that recent crises have affected mainly MFI economies has led to these phenomena being regarded as hallmarks of the unequal distribution of globalization's benefits and risks. This raises a challenging set of questions about whether the nature of crises has changed over time, what factors increase vulnerability to crises, and whether such crises are an inevitable concomitant of globalization.

Some aspects of financial crises have indeed changed over time while, in other respects, it is often déjà vu all over again. Calvo (1998) has referred to such episodes in the latter half of the 1980s and 1990s as capital account crises, while earlier ones are referred to as current account crises. Although this suggests differences in the mechanics of crises, it does not necessarily imply differences in some of their fundamental causes. Kaminsky and Reinhart (1999) discuss the phenomenon of "twin crises," which involve balance-of-payments and banking crises. These authors also make the important point that, in the episodes that they analyze, banking sector problems typically precede a currency crisis and that the currency crisis then deepens the banking crisis, activating a vicious spiral. In this vein, Krueger and Yoo (2002) conclude that imprudent lending by the Korean banks in the early and mid-1990s, especially to the Chaebols, played a significant role in the 1997 Korean currency crisis. Opening up to capital markets can thus exacerbate such existing domestic distortions and lead to catastrophic consequences (Aizenman (2002)).

One key difference in the evolution of crises is that, while the 1970s and 1980s featured crises that affected both industrial and developing economies, these have become almost exclusively the preserve of developing economies since the mid 1990s. ${ }^{33}$ This suggests either that advanced economies have been able to better protect themselves through improved policies

\footnotetext{
${ }^{32}$ The World Bank's Global Development Finance Report (2001) also finds some evidence of such procyclicality and notes that the response of capital inflows is typically twice as large when a developing country faces an adverse shock to GDP growth as when it faces a favorable shock. This is attributed to the fact that credit ratings are downgraded more rapidly during adverse shocks than they are upgraded during favorable ones.

${ }^{33}$ In fact, in the 1990s, the ERM crisis is the only significant one among industrial countries. The prolonged Japanese recession is in some sense a crisis although the protracted nature of Japan's decline, which has not featured any sudden falls in output, would not fit into a standard definition of a crisis.
} 
or that the fundamental causes of crises have changed over time, thereby increasing the relative vulnerability of developing economies. In this context, it should be noted that, while capital flows from advanced economies to MFI economies have increased sharply, these flows among industrial economies have jumped even more sharply in recent years, as noted earlier. Thus, at least in terms of volume of capital flows, it is not obvious that changes in financial integration can by themselves be blamed for crises in MFI economies.

Is it reasonable to accept crises as a natural feature of globalization, much as business cycles are viewed as a natural occurrence in market economies? One key difference between these phenomena is that the overall macroeconomic costs of financial crises are typically very large and far more persistent. Calvo and Reinhart (2000,2002) document that emerging market currency crises, that are typically accompanied by sudden stops or reversals of external capital inflows, are associated with significant negative output effects. ${ }^{34}$ Such recessions following devaluations (or large depreciations) are also found to be much deeper in emerging markets than in developed economies. In addition, the absence of well-functioning safety nets can greatly exacerbate the social costs of crises, which typically have large distributional consequences (see, e.g., Baldacci, de Mello, and Inchauste (2002)). ${ }^{35}$

What is the impact on poverty of macroeconomic volatility associated with greater openness to trade and financial flows on poverty? Mechanically, an increase in the volatility of consumption could lead to a decrease in the poverty head count. However, the increase in the volatility of consumption adversely affects the poor households' welfare. Recent research examines various implications of macroeconomic volatility and financial crises on the dynamics of consumption and poverty in developing countries. For example, Duygan (2004) documents that household expenditure decreased by 5 percent on average during financial crises in sixteen developing countries. Some recent studies focus on the permanent impact of temporary negative income shocks on poverty. For example, Lustig (2002) concludes that crises in Latin America adversely affected the human capital of the poor and have had a permanent impact on poverty and inequality by diminishing the potential of the poor to escape poverty. Agenor (2002) studies the asymmetric effects of macroeconomic fluctuations and crises on poverty. He finds that while

\footnotetext{
${ }^{34}$ Currency crises can also affect firms directly and, by exacerbating the problems of the banking sector, can lead to a broader credit crunch, even for productive and solvent firms. Mishkin (1999) argues that the credit crunch resulting from sharp contractions in domestic bank credit following financial crises has been instrumental in aggravating these crises and reducing investment and economic activity. Rodrik and Velasco (2000) note that difficulties in rolling over short-term debt during crisis episodes rapidly squeeze the availability of liquidity, with immediate effects on investment and output.

${ }^{35}$ Work by Wu and Wei (2001) using Chinese regional data shows that increases in trade openness are negatively associated with changes in inequality. However, the process of financial and trade liberalization can sometimes have negative distributional consequences within a country, especially in the short run. Attempts to address these issues using ad hoc redistributive measures can often result in distortions that adversely affect long-term growth. Nevertheless, given the vital need to maintain sociopolitical stability while undertaking significant reforms and liberalization, there is a need for judicious design and use of social safety nets to protect the economically vulnerable segments of the population.
} 
the effects of shocks to income on poverty are quite small during periods of crisis, these shocks could decrease poverty during expansions. ${ }^{36}$

\section{Has Financial Globalization Intensified the Transmission of Volatility?}

What factors have led to the rising vulnerability of developing economies to financial crises? The risk of sudden stops or reversals of global capital flows to developing countries has increased in importance as many developing countries now rely heavily on borrowing from foreign banks or portfolio investment by foreign investors. These capital flows are sensitive not just to domestic conditions in the recipient countries but also to macroeconomic conditions in industrial countries. For instance, Mody and Taylor (2002), using an explicit disequilibrium econometric framework, detect instances of "international capital crunch"-where capital flows to developing countries are curtailed by supply-side rationing that reflects industrial country conditions. ${ }^{37}$ These North-South financial linkages, in addition to the real linkages described in earlier sections, represent an additional channel through which business cycles and other shocks that hit industrial countries can affect developing countries.

The effects of industrial country macroeconomic conditions, including the stage of the business cycle and interest rates, have different effects on various types of capital flows to emerging markets. Reinhart and Reinhart (2001) document that net FDI flows to emerging market economies are strongly positively correlated with U.S. business cycles. On the other hand, bank lending to these economies is negatively correlated with U.S. cycles. Edison and Warnock (2001) find that portfolio equity flows from the United States to major emerging market countries are negatively correlated with both U.S. interest rates and U.S. output growth. This result is particularly strong for flows to Latin America and less so for flows to Asia. Thus, the sources of capital inflows for a particular MFI can greatly affect the nature of its vulnerability to the volatility of capital flows arising from industrial country disturbances. ${ }^{38}$

The increase in cross-country financial market correlations also indicates a risk of emerging markets being caught up in financial market bubbles. The rise in comovement across emerging and industrial country stock markets, especially during the stock market bubble period of the late 1990s, points to the relevance of this concern. This is a particular risk for relatively shallow and undiversified stock markets of some emerging economies. For instance, as noted earlier, the strong correlations between emerging and industrial stock markets during the bubble period reflects the preponderance of technology and telecommunication sectors stocks in

\footnotetext{
${ }^{36}$ Recent research also studies the adverse impact of macroeconomic volatility on food security and hunger (see Barrett and Shan, 2001).

${ }^{37}$ This paper examines bond, equity and syndicated loan flows to Brazil, Mexico, Korea and Thailand over the period 1990-2000.

${ }^{38}$ However, notwithstanding the differences in the types of sensitivities to industrial country business cycle conditions, the fact still remains that FDI flows are generally less volatile and less sensitive to the factors discussed here than either portfolio flows or bank lending.
} 
the former set of markets. It is, of course, difficult to say conclusively whether this phenomenon would have occurred even in the absence of financial globalization, since stock market liberalizations in these countries often went hand in hand with their opening up to capital flows.

The increasing depth of stock markets in emerging economies could alleviate some of these risks but, at the same time, could heighten the real effects of such financial shocks. In this vein, Dellas and Hess (2002) find that a higher degree of financial development makes emerging stock markets more susceptible to external influences (both financial and macroeconomic) and that this effect remains important after controlling for capital controls and trade linkages. ${ }^{39}$ Consequently, the effects of external shocks could be transmitted to domestic real activity through the stock market channel.

Even the effects of real shocks are often transmitted faster and amplified through financial channels. There is a large literature showing how productivity, terms of trade, fiscal and other real shocks are transmitted through trade channels. ${ }^{40}$ Cross-country investment flows, in particular, have traditionally responded quite strongly to country-specific shocks. ${ }^{41}$ Financial channels constitute an additional avenue through which the effects of such real shocks can be transmitted. Furthermore, since transmission through financial channels is much quicker than through real channels, both the speed and magnitude of international spillovers of real shocks are considerably heightened by financial linkages. ${ }^{42}$

Rising financial linkages have also resulted in contagion effects. Potential contagion effects are likely to become more important over time as financial linkages increase and investors in search of higher returns and better diversification opportunities increase their share of international holdings and, due to declines in information and transaction costs, have access to a broader array of cross-country investment opportunities. ${ }^{43}$

There are two broad types of contagion identified in the literature-fundamentals-based contagion and "pure" contagion. The former refers to the transmission of shocks across national borders through real or financial linkages. In other words, while an economy may have weak fundamentals, it could get tipped over into a financial crisis as a consequence of investors reassessing the riskiness of investments in that country or attempting to rebalance their portfolios

\footnotetext{
${ }^{39}$ These authors use standard measures of financial sector development that are based on the competitive structure and the size of the financial intermediation sector in each country.

${ }^{40}$ See Kouparitsas (1996); Blankenau, Kose, and Yi (2001); Kose and Riezman (2001); and Kose (2002).

${ }^{41}$ See Glick and Rogoff (1997) for an empirical analysis of how country-specific productivity shocks affect national investment and the current account. These authors show how the responses to such shocks depend crucially on the persistence of the shocks. Kose, Otrok, and Whiteman (2003) examine the impact of world and country-specific factors in driving fluctuations in output, consumption, and investment.

${ }^{42}$ For instance, a shock to GDP growth in one country may be transmitted gradually through trade channels but could far more quickly have an impact on economic activity in another country via correlations in stock market fluctuations. If the two countries were perfectly integrated through trade and financial linkages this outcome could, of course, simply reflect an optimal risk-sharing arrangement.

${ }^{43}$ Contagion effects aside, Kose, Prasad, and Terrones (2003b) find that increasing financial linkages have only a small effect on cross-country output and consumption correlations.
} 
following a crisis in another country. Similarly, bank lending can lead to such contagion effects when a crisis in one country to which a bank has significant exposure forces it to rebalance its portfolio by readjusting its lending to other countries. This bank transmission channel, documented in Van Rijckeghem and Weder (2000) and Kaminsky and Reinhart (2001), can be particularly potent since a large fraction of bank lending to emerging markets is in the form of short-maturity loans. While fundamentals-based contagion was once prevalent mainly at the regional level, the Russian crisis demonstrated its much broader international reach (Kaminsky and Reinhart (2002)). ${ }^{44}$

Pure contagion, on the other hand, represents a different kind of risk since it can not easily be influenced by domestic policies at least in the short run. There is a good deal of evidence of sharp swings in international capital flows that are not obviously related to changes in fundamentals. Investor behavior during these episodes, which is sometimes categorized as herding or momentum trading, is difficult to explain in the context of optimizing models with full and common information. Informational asymmetries, which are particularly rife in the context of emerging markets, appear to play an important role in this phenomenon. A related literature suggests that pure contagion may reflect investors' shifting "appetite" for risk, but it is no doubt difficult to disentangle such changes in risk appetite from shifts in underlying risks themselves (Kumar and Persaud (2001)). Thus, in addition to "pure contagion," financial integration exposes developing economies to the risks associated with destabilizing investor behavior that is not related to fundamentals. ${ }^{45}$

\section{Some Factors That Increase Vulnerability to the Risks of Globalization}

Empirical research indicates that the composition of capital inflows and the maturity structure of external debt appear to be associated with higher vulnerability to the risks of financial globalization. The relative importance of different sources of financing for domestic investment, as proxied by the following three variables, has been shown to be positively associated with the incidence and the severity of currency and financial crises: the ratio of bank borrowing or other debt relative to foreign direct investment; the shortness of the term structure of external debt; and the share of external debt denominated in foreign currencies. ${ }^{46}$ Detragiache and Spilimbergo (2002) find strong evidence that debt crises are more likely to occur in countries where external debt has a short maturity. ${ }^{47}$ However, the maturity structure may not entirely be a

\footnotetext{
${ }^{44}$ Kim, Kose, and Plummer (2001) examine the roles of fundamentals based contagion and pure contagion during the Asian crisis.

${ }^{45}$ Claessens and Forbes (2001) contains a compilation of essays on the different dimensions of contagion effects. Boyer, Gibson, and Loretan (1999), and Forbes and Rigobon (2001) argue that the evidence for pure contagion against the alternative of fundamentals-based contagion is very weak. Corsetti and others (2002) argue that, under more general assumptions, there is greater evidence of the former type of contagion. Bayoumi and others (2003), find evidence of "positive" contagion related with herding behavior of capital inflows to emerging markets.

${ }^{46}$ See, for example, Frankel and Rose (1996), Radelet and Sachs (1998), and Rodrik and Velasco (1999).

${ }^{47}$ Some authors have found that the currency composition of external debt also matters. Carlson and Hernandez (2002) note that, during the Asian crisis, countries with more yen-denominated debt fared
} 
matter of choice since, as argued by these authors, countries with weaker macroeconomic fundamentals are often forced to borrow at shorter maturities since they do not have access to longer-maturity loans.

In addition to basic macroeconomic policies, other policy choices of a systemic nature can also affect the vulnerability of MFIs. Recent currency crises have highlighted one of the main risks in this context. Developing countries that attempt to maintain a relatively inflexible exchange rate system often face the risk of attacks on their currencies. While various forms of fully or partially fixed exchange rate regimes can have some advantages, the absence of supportive domestic policies can often result in an abrupt unraveling of these regimes when adverse shocks hit the economy.

Financial integration can also aggravate the risks associated with imprudent fiscal policies. Access to world capital markets could lead to excessive borrowing that is channeled into unproductive government spending. The existence of large amounts of short-term debt denominated in hard currencies then makes countries vulnerable to external shocks or changes in investor sentiment. The experience of a number of MFI countries that have suffered the consequences of such external debt accumulation points to the heightened risks of undisciplined fiscal policies when the capital account is open.

Premature opening of the capital account also poses serious risks when financial regulation and supervision are inadequate. ${ }^{48}$ In the presence of weakly regulated banking systems and other distortions in domestic capital markets, inflows of foreign capital could exacerbate the existing inefficiencies in these economies. For example, if domestic financial institutions tend to channel capital to firms with excessive risks or weak fundamentals, financial integration could simply lead to an intensification of such flows. ${ }^{49}$ In turn, the effects of premature capital inflows on the balance sheets of the government and corporate sectors could have negative repercussions on the health of financial institutions in the event of adverse macroeconomic shocks.

\section{Conclusions}

The empirical evidence has not established a definitive proof that financial integration has enhanced growth for developing countries. Furthermore, it may be associated with higher consumption volatility. Therefore, there may be value for developing countries to experiment with different paces and strategies in pursuing financial integration. Empirical evidence does suggest that improving governance, in addition to sound macroeconomic frameworks and the development of domestic financial markets, should be an important element of such strategies. This conclusion does not necessarily imply that a country must develop a full set of sound institutions matching the best practices in the world before embarking on financial integration.

significantly worse. These authors attribute this to the misalignment between the countries' de facto currency pegs and the denomination of their debt.

${ }^{48}$ See Ishii and Habermeier (2002) and Bakker and Chapple (2002).

${ }^{49}$ Krueger and Yoo (2002), discuss the interactions of crony capitalism and capital account liberalization in setting the stage for the currency-financial crisis in Korea. See also, Mody (2002). 
As emphasized in Prasad, Rogoff, Wei and Kose (2003, chapter 5), as a country makes progress on transparency, control of corruption, rule of law, and financial supervisory capacity, it will be in an increasingly better position to benefit from financial globalization.

Equally important is to avoid some of the recurrent traps that countries have fallen into as they have moved to liberalize domestic financial markets and engineer increased financial globalization. If, as appears to be the case, overly fixed exchange rates are a leading determinant of financial crises in emerging markets, then moving to more flexible exchange rate regimes should greatly improve a country's chances of being a winner from financial globalization even in the short term. Likewise, assuming a large external debt burden, especially if it is of a relatively short maturity structure, can be a damaging way to undertake financial integration.

It is also important to stress that financial integration is not necessarily a variable that can be tightly controlled by policy. Capital controls, aside from coming in myriads of forms with effects that are difficult to manage, are often ineffective. Even in counties where they are relatively more effective, such controls tend to become less so over time as the rising sophistication of international capital markets and investors, along with the global expansion of trade, increase the opportunities for evading capital controls. Some of the most consistently financially integrated countries based on our de facto measure--including, for example, many Latin American countries--have often been ones where capital controls are quite stringent, at least on paper. On the other hand, many countries in Africa offer unimpeded capital market access, have not yet succeeded in achieving a significant degree of integration.

Finally, given that we have not been able to draw strong conclusions about the empirical links between financial globalization, growth and macroeconomic volatility, one must conclude that there will almost surely be similar ambiguity in an investigation of the links between financial globalization and poverty, although we have not directly examined those links in this paper. Of course, in such an exercise one would ideally like to look at a broader range of human development indicators and measures of poverty than just income (for example, even in some countries such as Brazil that have experienced relatively slow income growth over the past fifteen years, educational attainment levels have continued to rise). ${ }^{50}$

In addition, to provide a comprehensive analysis of the complex relationship between globalization and poverty, one has to acknowledge that poverty is fundamentally a relative measure which would probably gain an entirely different meaning as the world economy become more integrated (Rogoff, 2004). For example, if global growth continues at a rapid pace during the next century, it is possible that emerging market economies, including China and India, could attain income levels exceeding those of Americans today by the end of the century. This implies that Malthusian notions of poverty are likely to become a distant memory in most parts of the world as global income inexorably expands over the next century, and issues of inequality, rather than subsistence, will increasingly take center stage in the poverty debate.

\footnotetext{
${ }^{50}$ Ravallion (2003) argues that differences in the concept and definitions of poverty could lead to different conclusions about the impact of globalization on poverty and inequality.
} 
The results that we have highlighted in this paper provide a framework in which to examine the different channels through which the forces of financial globalization could affect poverty and inequality outcomes. A great deal of additional work is clearly called for to gain a better understanding of these dimensions of the effects of financial globalization. 
Figure 1. Measures of Financial Integration
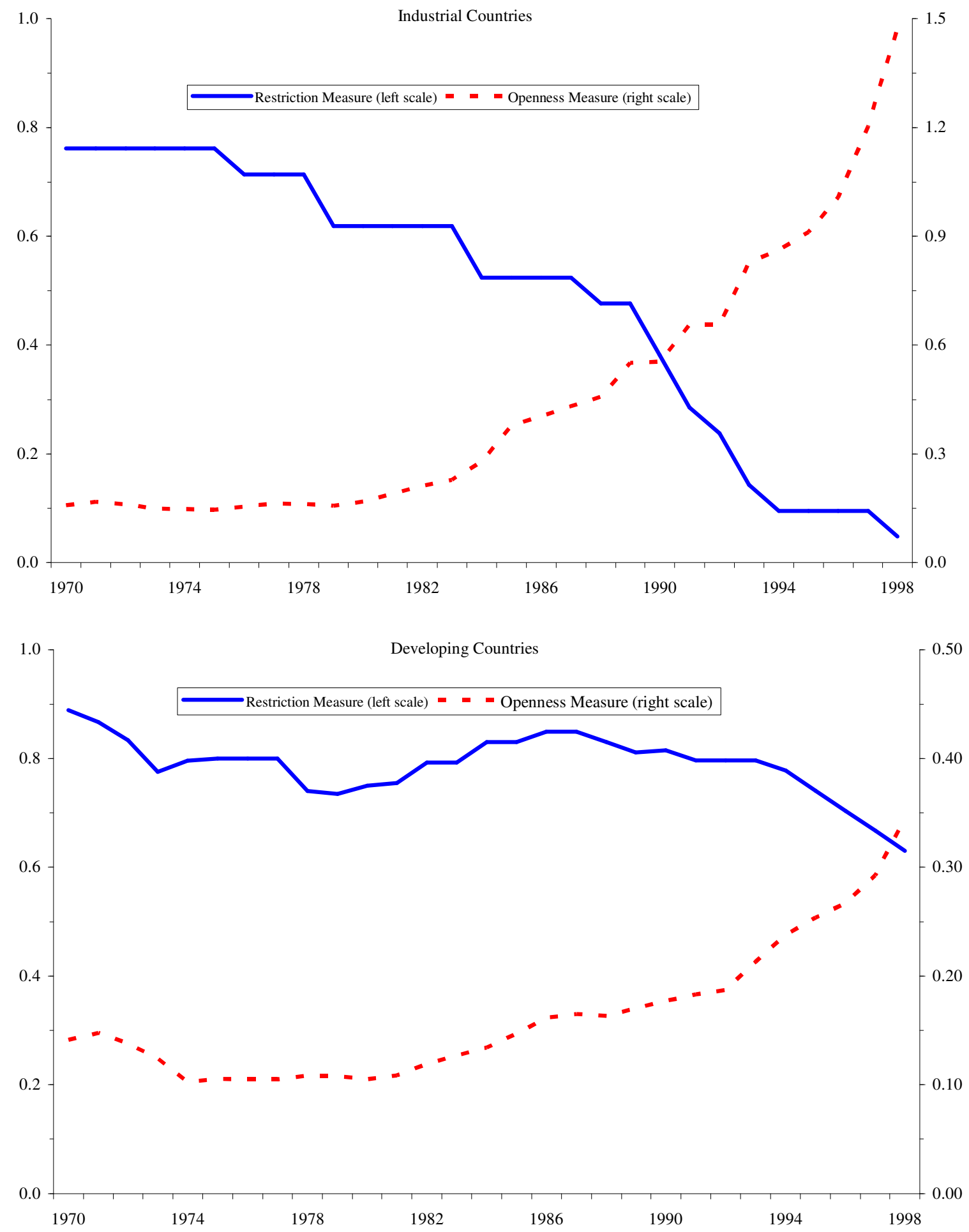

Source: WEO, Lane and Milesi-Ferreti (2003) 
Figure 2. Gross Capital Flows

\section{(Percent of GDP)}

More Financially Integrated Economies

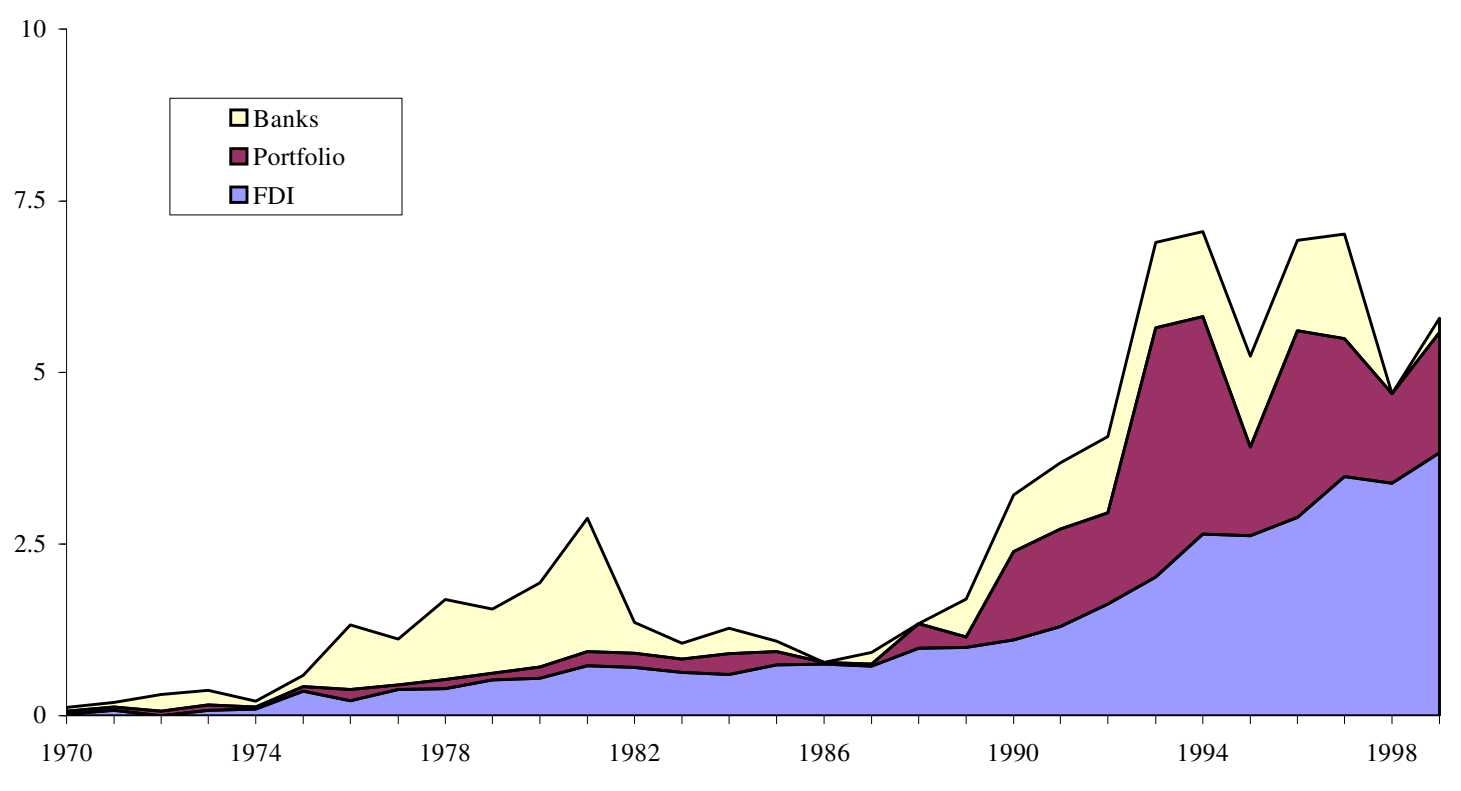

Less Financially Integrated Economies

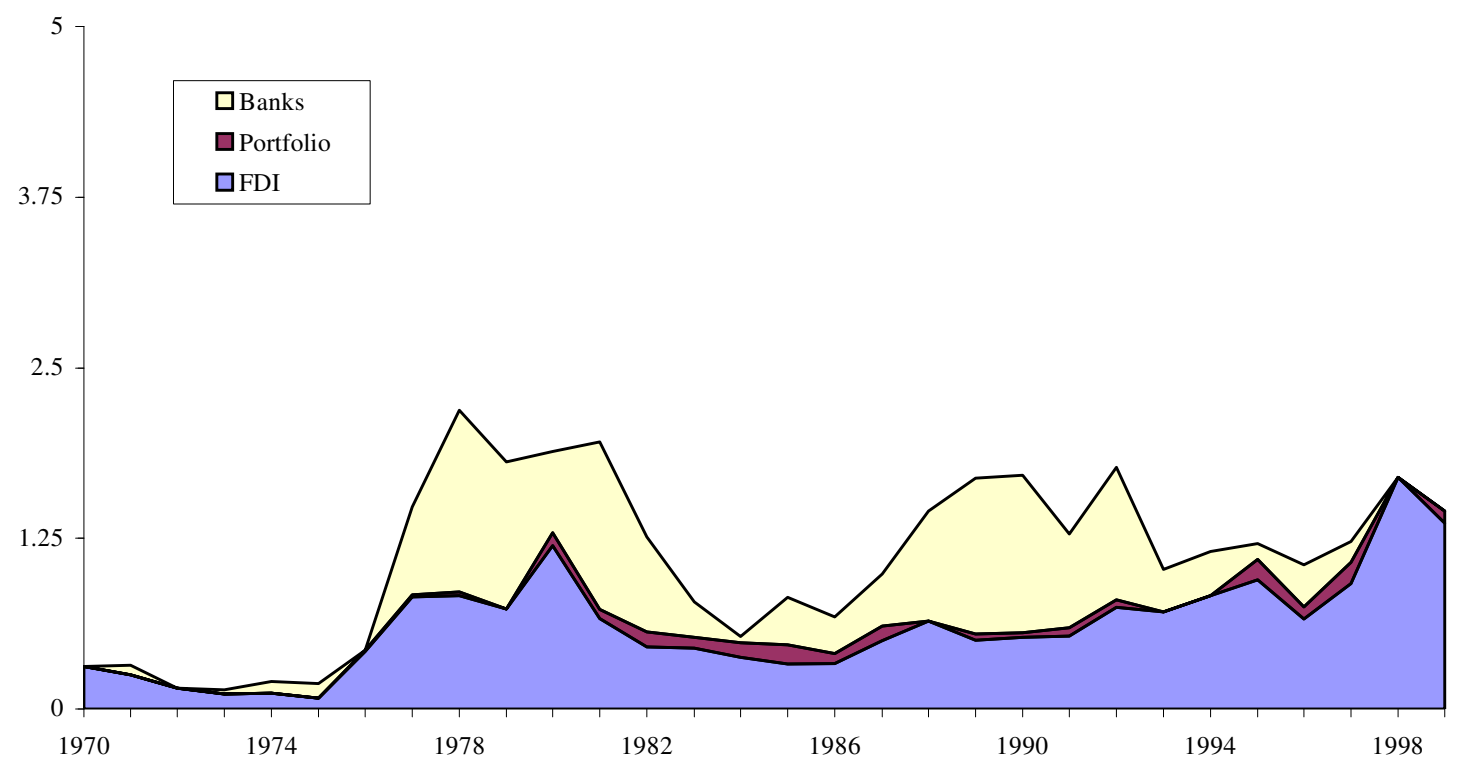

Source: WEO, IFS

Note that the left scales on the two panels are different 
Figure 3. Net Private Capital Flows

(Billions of U.S. dollars)

All Developing Economies

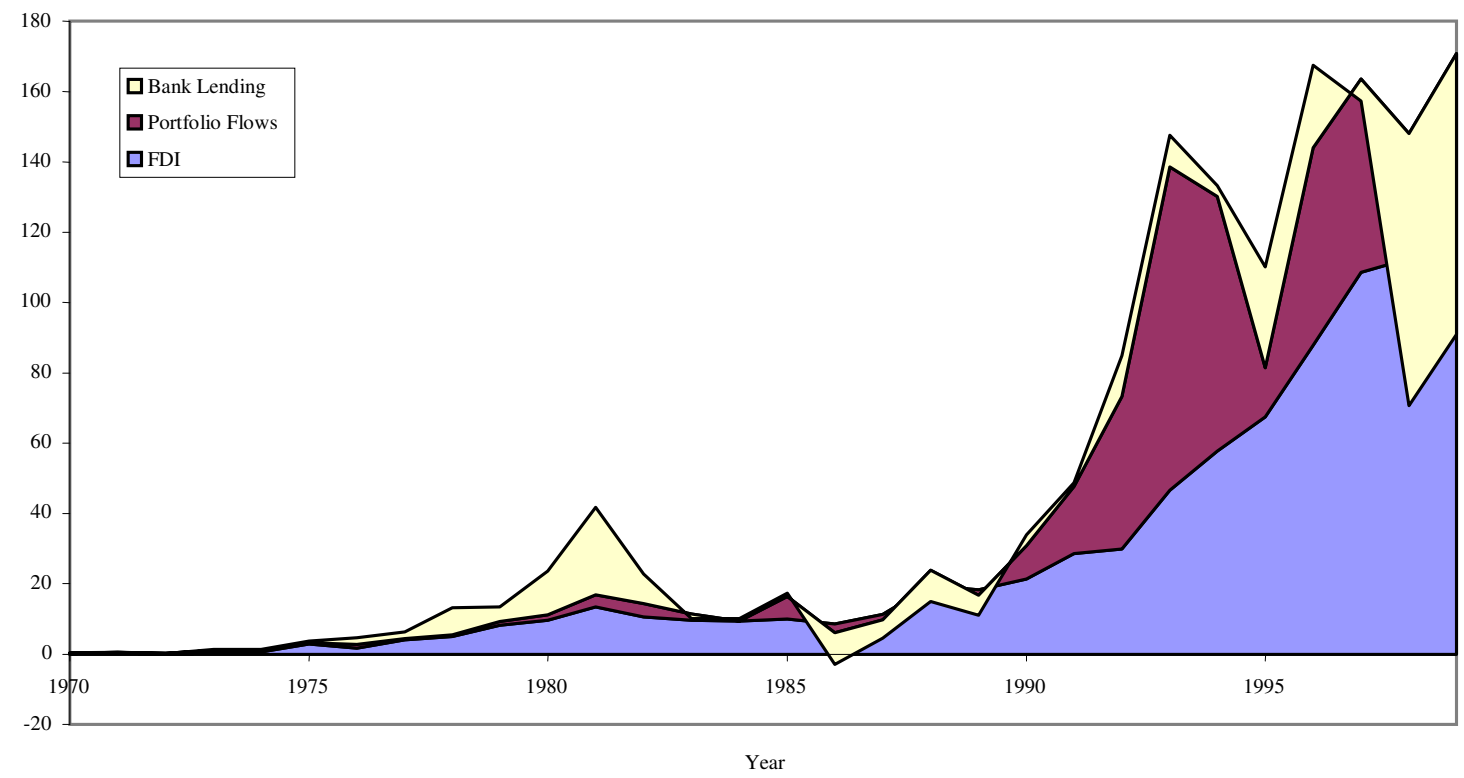

More Financially Integrated Economies

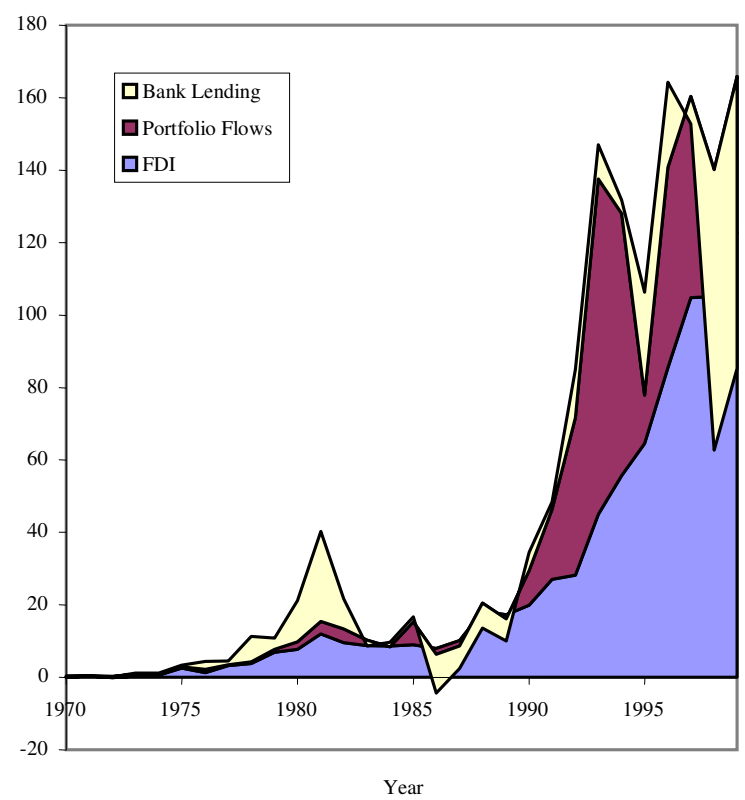

Less Financially Integrated Economies

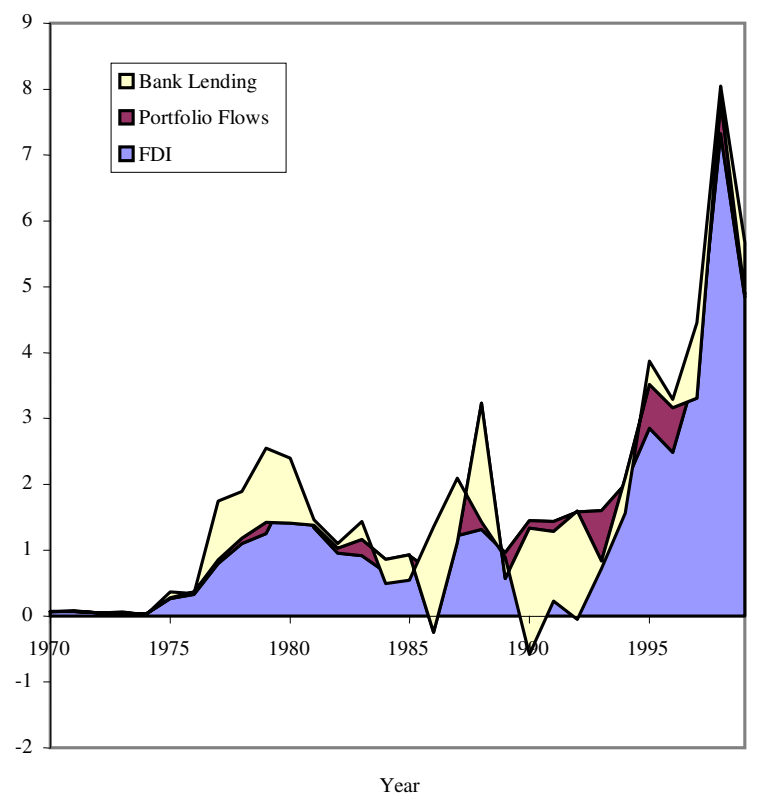

Source: WEO

Note: Bank lending to the More Financially Integrated Economies was negative between 1997 and 1999. 
Figure 4. Foreign Ownership Restrictions

(More Financially Integrated Developing Economies)

Total

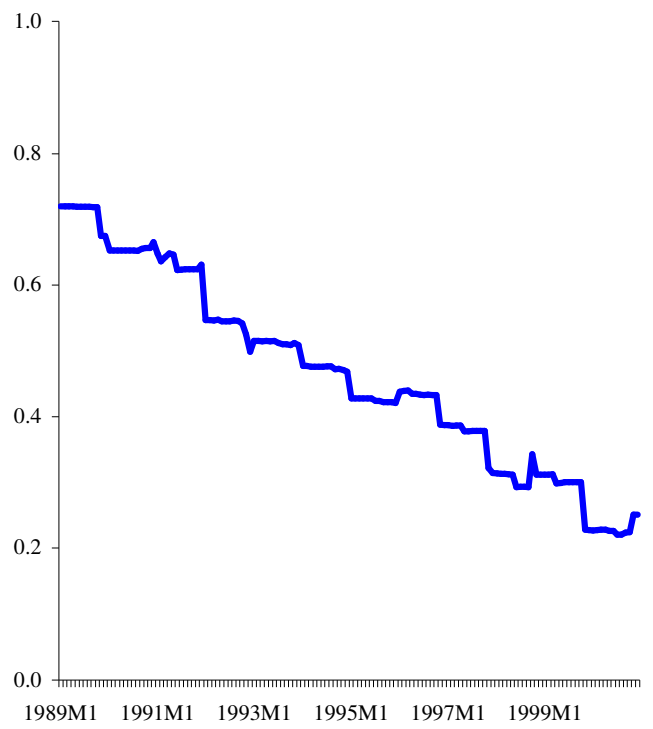

Western Hemisphere

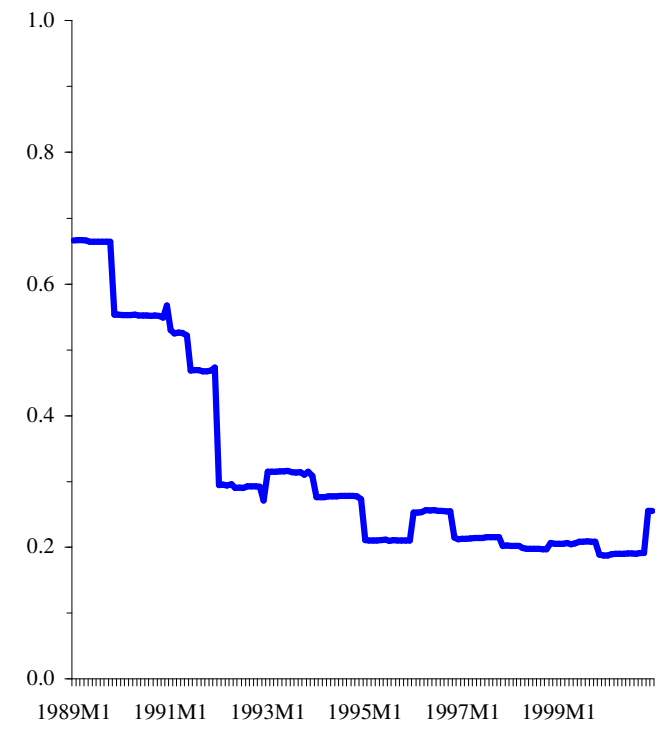

Asia

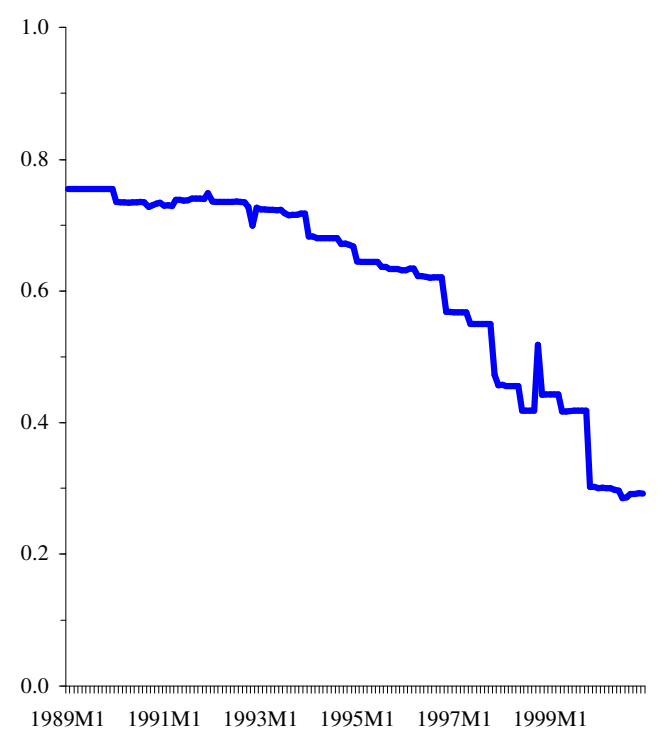

Africa

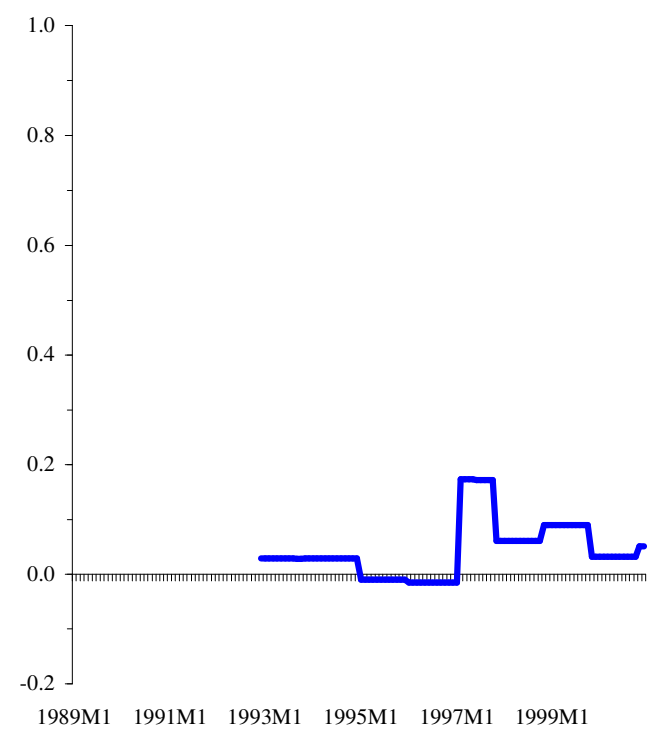

Source: Edison and Warnock (2001).

Note: This index measures the intensity of restrictions on the access that foreign investors have to a particular country's equity markets. 
Figure 5. Channels Through Which Financial Integration Can

Raise Economic Growth

\section{International Financial Integration}

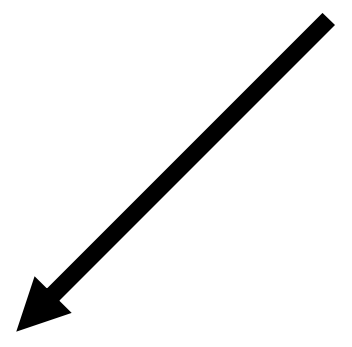

\section{Direct Channels}

- Augmentation of domestic savings

- Lower cost of capital due to better risk allocation

- Transfer of technology

- Development of financial sector

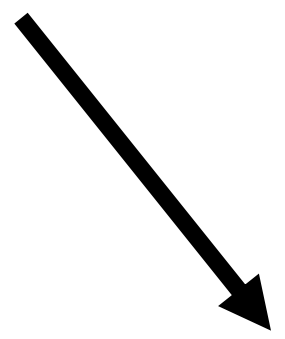

\section{Indirect Channels}

- Promotion of specialization

- Inducement for better policies

- Enhancement of capital inflows by signaling better policies
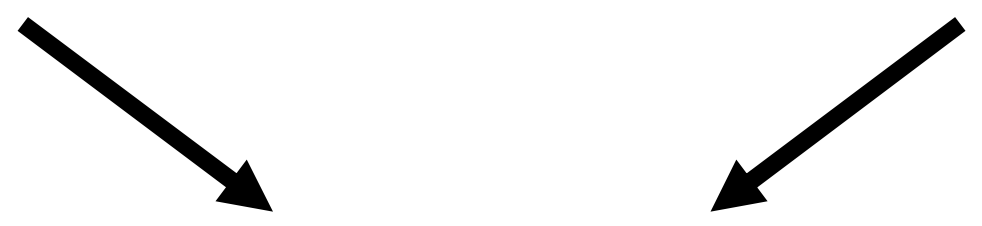

Higher Economic Growth

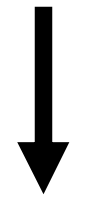

Lower Poverty 
Figure 6. Increase in Financial Openness and Growth of Real Per Capita GDP

Simple Correlation, 1982-97

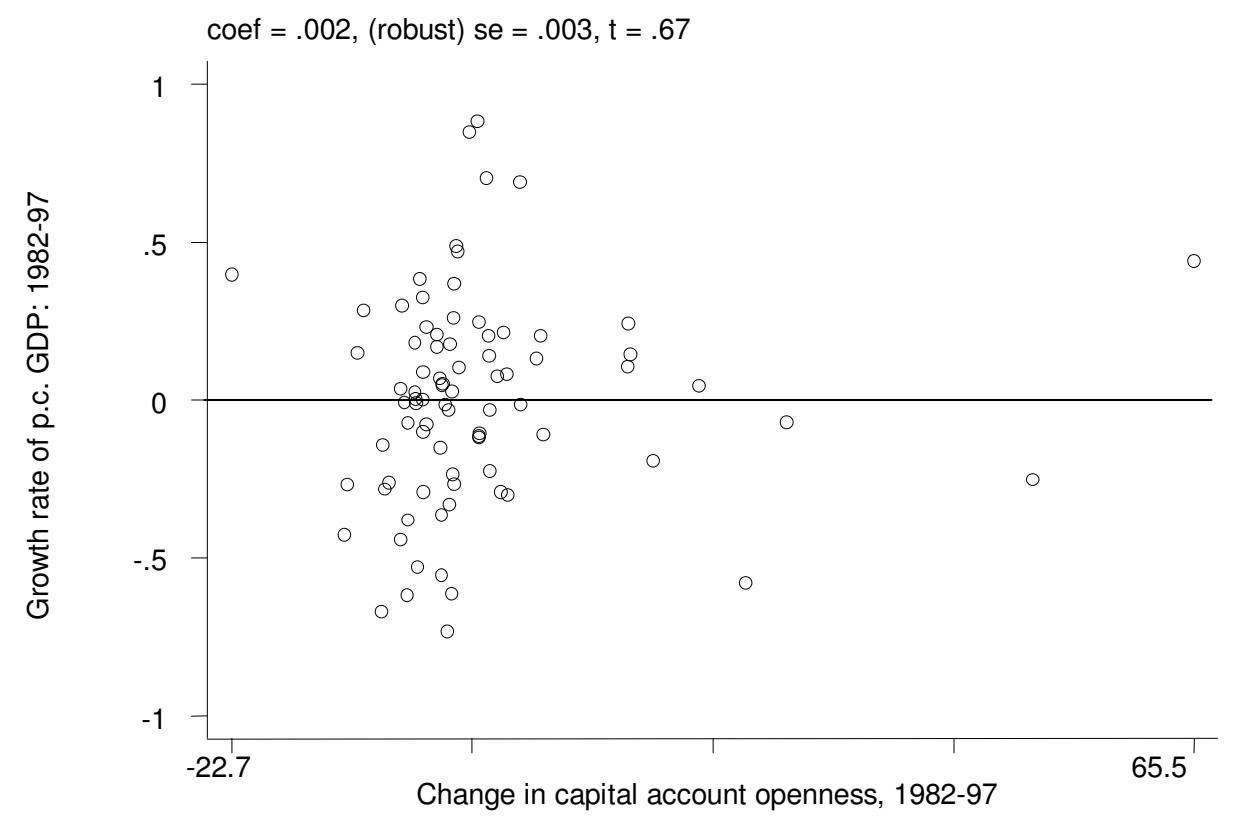

Note: Capital account openness is measured as (gross private capital inflows + gross private capital outflows) / GDP.

Source: Wei and Wu (2002b). 
Figure 7. Increase in Financial Openness and Growth of Real Per Capita GDP: Conditional Relationship, 1982-1997

Conditioning on Initial Income, Initial Schooling, Average Investment/GDP, Political Instability (Revolution and Coup), and Regional Dummies, 1982-97

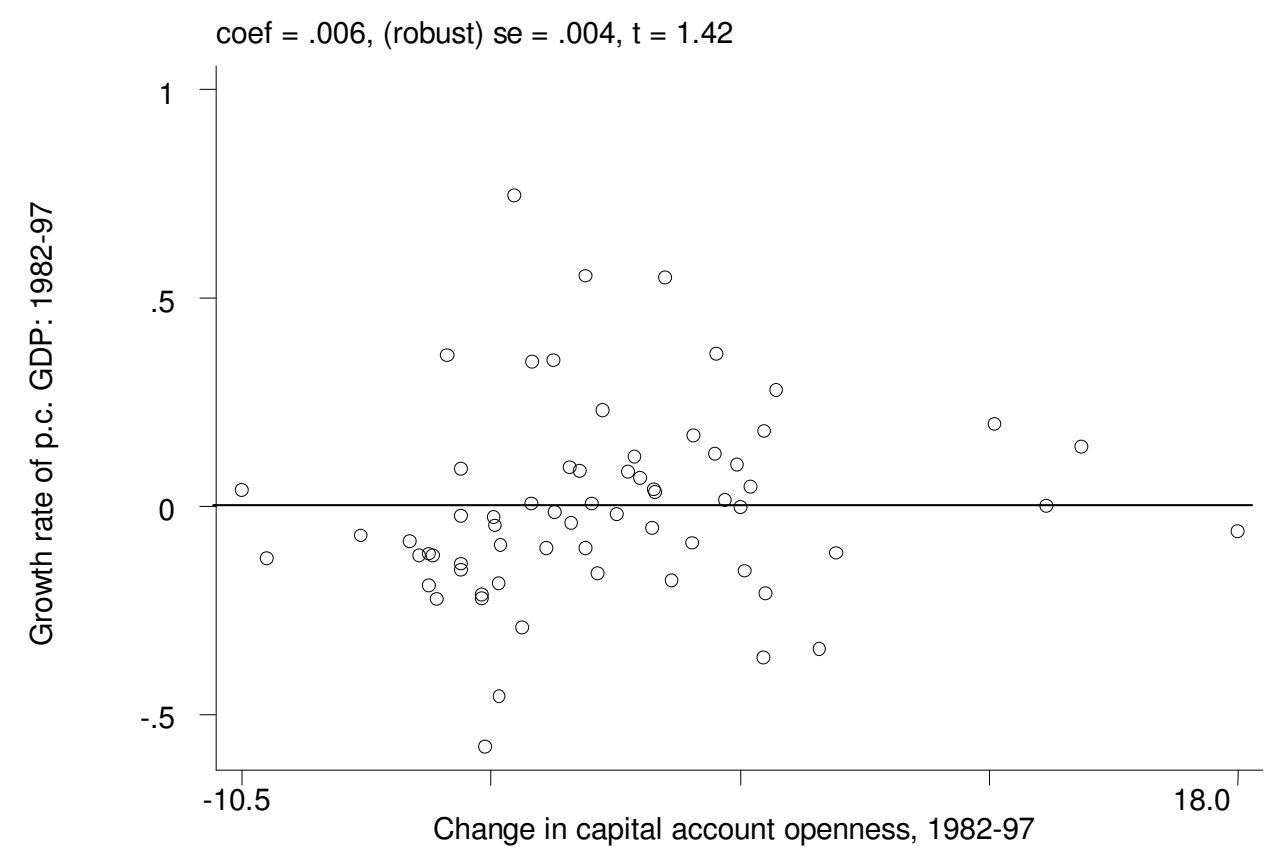

Note: Capital account openness is measured by the (gross private capital inflows + gross private capital outflows) / GDP.

Source: Wei and Wu (2002b). 
Figure 8. Volatility of Income and Consumption Growth

(10-year rolling standard deviations; medians for each group of countries)

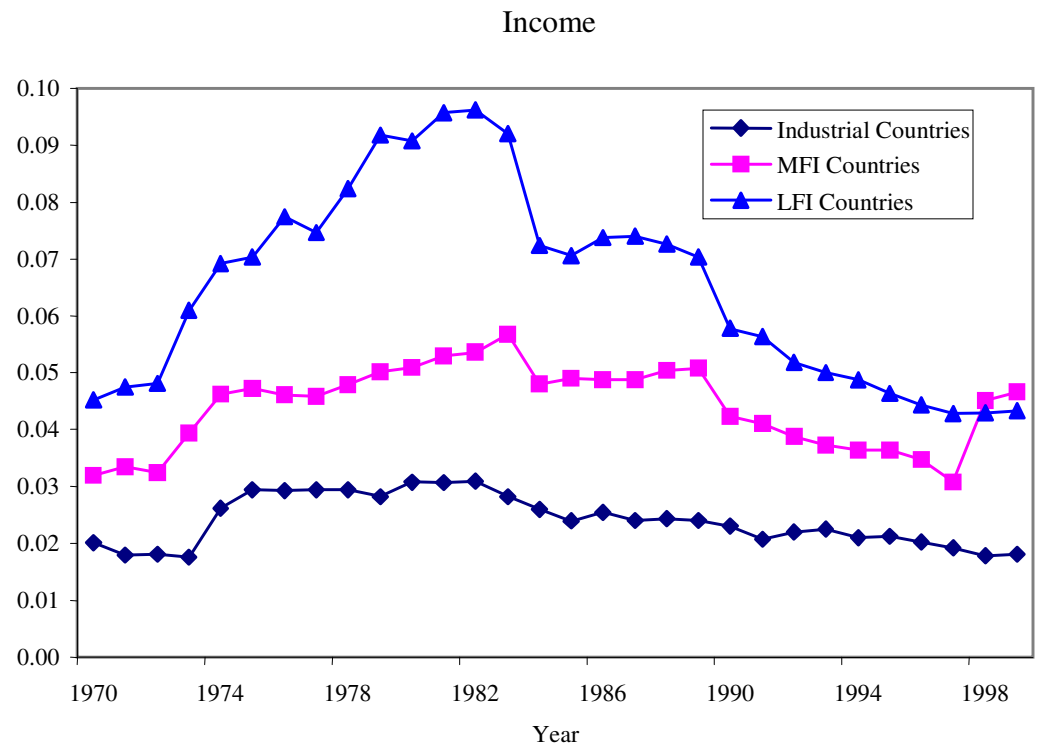

Total Consumption

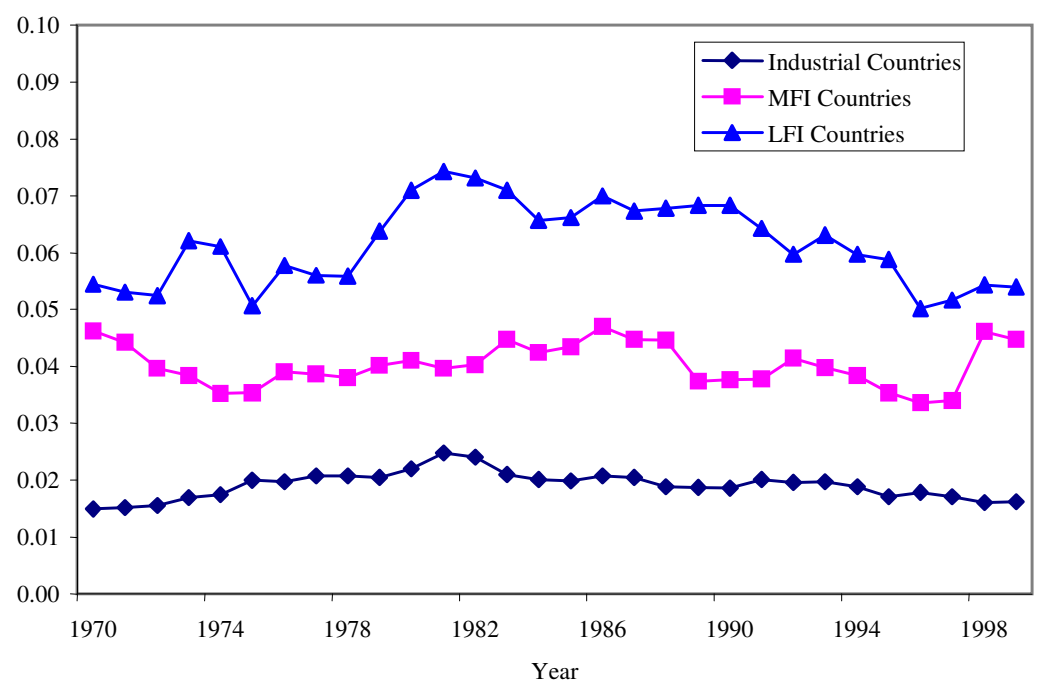

Source: Kose, Prasad and Terrones (2003a) 
Table 1. Volatility of Different Types of Capital Inflows

FDI/GDP Loan/GDP $\quad$ Portfolio/GDP

\section{Standard deviations}

(median for each group)

MFI economies

0.007

0.032

0.009

LFI economies

0.010

0.036

0.002

\section{Coefficients of variation}

(median for each group)

$\begin{array}{llll}\text { MFI economies } & 0.696 & 1.245 & 1.751 \\ \text { LFI economies } & 1.276 & 1.177 & 2.494\end{array}$

\section{Coefficients of variation}

for selected MFI economies

Indonesia

Korea

Malaysia

Mexico

Philippines

Thailand
0.820

0.717

2.039

4.397

2.048

0.956

0.629
1.722

1.338

3.544

2.088

1.979

1.137

Source: Wei (2001). Computed over the period 1980-96. Only countries with at least eight non-missing observations during the period for all three variables and with a population greater than or equal to one million in 1995 are kept in the sample. Total inward FDI flows, total bank loans, and total inward portfolio investments are from the IMF's Balance of Payments Statistics, various issues. 
Table 2. Fastest and Slowest Growing Economies

During 1980-2000 and Their Status of Financial Openness

\begin{tabular}{|l|l|l|l|l|l|l|l|}
\hline & $\begin{array}{l}\text { Fastest Growing } \\
\text { Economies, } \\
1980-2000\end{array}$ & $\begin{array}{l}\text { Total } \\
\text { Percentage } \\
\text { Change in } \\
\text { p.c. GDP } \\
\text { Financially } \\
\text { Integrated? }\end{array}$ & $\begin{array}{l}\text { More } \\
\text { Economies, } \\
1980-2000\end{array}$ & $\begin{array}{l}\text { Total } \\
\text { Percentage } \\
\text { Change in } \\
\text { p.c. GDP }\end{array}$ & $\begin{array}{l}\text { More } \\
\text { Financially } \\
\text { Integrated? }\end{array}$ \\
\hline 1 & China & 391.6 & Yes/No & Haiti & Niger & -39.5 & No \\
\hline 2 & Korea & 234.0 & Yes & Yes & Nicaragua & -30.6 & No \\
\hline 3 & Singapore & 155.5 & Yes & Togo & -30.0 & No \\
\hline 4 & Thailand & 151.1 & No & Cote d'Ivoire & -29.0 & No \\
\hline 5 & Mauritius & 145.8 & 135.4 & No & Burundi & -20.2 & No \\
\hline 6 & Botswana & 114.5 & Yes & Venezuela & -17.3 & Yes/No \\
\hline 7 & Hong Kong SAR & 108.8 & Yes & South Africa & -13.7 & Yes \\
\hline 8 & Malaysia & 103.2 & Yes/No & Jordan & -10.9 & Yes \\
\hline 9 & India & 100.9 & Yes & Paraguay & -9.5 & No \\
\hline 10 & Chile & Indonesia & 97.6 & Yes & Ecuador & -7.9 & No \\
\hline 12 & Sri Lanka & 90.8 & No & Peru & & Yes \\
\hline
\end{tabular}

Note: Growth rate of real per capita GDP, in constant local currency units.

Source: These calculations are based on the World Bank's World Development Indicators (WDI) database. 
Table 3. Summary of Recent Research on Financial Integration and Economic Growth

\begin{tabular}{lccc}
\hline Study & $\begin{array}{c}\text { Number of } \\
\text { Countries }\end{array}$ & $\begin{array}{c}\text { Years } \\
\text { Covered }\end{array}$ & Effect on Growth \\
\hline Alesina, Grilli, and Milesi-Ferretti (1994) & 20 & $1950-89$ & No effect \\
Grilli and Milesi-Ferretti (1995) & 61 & $1966-89$ & No effect \\
Quinn (1997) & 58 & $1975-89$ & Positive \\
Kraay (1998) & 117 & $1985-97$ & No effect / mixed \\
Rodrik (1998) & 95 & $1975-89$ & No effect \\
Klein and Olivei (2000) & Up to 92 & $1986-95$ & Positive \\
Chanda (2001) & 116 & $1976-95$ & Mixed \\
Arteta, Eichengreen, and Wyplosz (2001) & $51-59$ & $1973-92$ & Mixed \\
Bekaert, Harvey, and Lundblad (2001) & 30 & $1981-97$ & Positive \\
Edwards (2001) & 62 & $1980 \mathrm{~s}$ & No effect for poor countries \\
O'Donnell (2001) & 94 & $1971-94$ & No effect, or at best mixed \\
Reisen and Soto (2001) & 44 & $1986-97$ & Mixed \\
Edison, Klein, Ricci, and Sløk (2002) & Up to 89 & $1973-95$ & Mixed \\
Edison, Levine, Ricci, and Sløk (2002) & 57 & $1980-2000$ & No effect \\
& & & \\
\hline
\end{tabular}


Table 4. Volatility of Annual Growth Rates of Selected Variables (Percentage standard deviations, medians for each group of countries)

\begin{tabular}{|c|c|c|c|c|c|}
\hline & \multirow{2}{*}{$\begin{array}{c}\text { Full Sample } \\
1960-99\end{array}$} & \multicolumn{4}{|c|}{ Decade } \\
\hline & & $1960 \mathrm{~s}$ & $1970 \mathrm{~s}$ & $1980 \mathrm{~s}$ & $1990 \mathrm{~s}$ \\
\hline \multicolumn{6}{|l|}{ Output (Y) } \\
\hline Industrial countries & $\begin{array}{l}2.18 \\
(0.23)\end{array}$ & $\begin{array}{c}1.91 \\
(0.26)\end{array}$ & $\begin{array}{c}2.46 \\
(0.28)\end{array}$ & $\begin{array}{c}2.03 \\
(0.30)\end{array}$ & $\begin{array}{c}1.61 \\
(0.14)\end{array}$ \\
\hline MFI economies & $\begin{array}{l}3.84 \\
(0.20)\end{array}$ & $\begin{array}{c}3.31 \\
(0.42)\end{array}$ & $\begin{array}{c}3.22 \\
(0.37)\end{array}$ & $\begin{array}{c}4.05 \\
(0.44)\end{array}$ & $\begin{array}{c}3.59 \\
(0.62)\end{array}$ \\
\hline LFI economies & $\begin{array}{l}4.67 \\
(0.35)\end{array}$ & $\begin{array}{c}3.36 \\
(0.61)\end{array}$ & $\begin{array}{c}4.88 \\
(1.01)\end{array}$ & $\begin{array}{c}4.53 \\
(0.69)\end{array}$ & $\begin{array}{c}2.70 \\
(0.38)\end{array}$ \\
\hline \multicolumn{6}{|l|}{ Income $(\mathbf{Q})$} \\
\hline Industrial countries & $\begin{array}{l}2.73 \\
(0.34)\end{array}$ & $\begin{array}{c}2.18 \\
(0.33)\end{array}$ & $\begin{array}{c}2.99 \\
(0.40)\end{array}$ & $\begin{array}{c}2.54 \\
(0.29)\end{array}$ & $\begin{array}{c}1.91 \\
(0.30)\end{array}$ \\
\hline MFI economies & $\begin{array}{l}5.44 \\
(0.50)\end{array}$ & $\begin{array}{c}3.60 \\
(0.47)\end{array}$ & $\begin{array}{c}5.43 \\
(0.45)\end{array}$ & $\begin{array}{c}5.45 \\
(0.65)\end{array}$ & $\begin{array}{c}4.78 \\
(0.72)\end{array}$ \\
\hline LFI economies & $\begin{array}{l}7.25 \\
(0.84)\end{array}$ & $\begin{array}{c}4.42 \\
(0.53)\end{array}$ & $\begin{array}{c}9.64 \\
(1.24)\end{array}$ & $\begin{array}{c}7.56 \\
(1.23)\end{array}$ & $\begin{array}{c}4.59 \\
(0.54)\end{array}$ \\
\hline \multicolumn{6}{|l|}{ Consumption ( C) } \\
\hline Industrial countries & $\begin{array}{l}2.37 \\
(0.30)\end{array}$ & $\begin{array}{c}1.47 \\
(0.27)\end{array}$ & $\begin{array}{c}2.16 \\
(0.25)\end{array}$ & $\begin{array}{c}1.98 \\
(0.28)\end{array}$ & $\begin{array}{c}1.72 \\
(0.20)\end{array}$ \\
\hline MFI economies & $\begin{array}{l}5.18 \\
(0.51)\end{array}$ & $\begin{array}{c}4.57 \\
(0.49)\end{array}$ & $\begin{array}{c}4.52 \\
(1.04)\end{array}$ & $\begin{array}{c}4.09 \\
(0.94)\end{array}$ & $\begin{array}{c}4.66 \\
(0.46)\end{array}$ \\
\hline LFI economies & $\begin{array}{l}6.61 \\
(0.78)\end{array}$ & $\begin{array}{c}5.36 \\
(0.58)\end{array}$ & $\begin{array}{c}7.07 \\
(0.11)\end{array}$ & $\begin{array}{c}7.25 \\
(0.81)\end{array}$ & $\begin{array}{c}5.72 \\
(0.78)\end{array}$ \\
\hline \multicolumn{6}{|c|}{ Total Consumption $(\mathbf{C}+\mathbf{G})$} \\
\hline Industrial countries & $\begin{array}{l}1.86 \\
(0.23)\end{array}$ & $\begin{array}{c}1.38 \\
(0.28)\end{array}$ & $\begin{array}{c}1.84 \\
(0.18)\end{array}$ & $\begin{array}{c}1.58 \\
(0.19)\end{array}$ & $\begin{array}{c}1.38 \\
(0.20)\end{array}$ \\
\hline MFI economies & $\begin{array}{l}4.34 \\
(0.47)\end{array}$ & $\begin{array}{c}3.95 \\
(0.51)\end{array}$ & $\begin{array}{c}4.19 \\
(0.54)\end{array}$ & $\begin{array}{c}3.43 \\
(0.84)\end{array}$ & $\begin{array}{c}4.10 \\
(0.53)\end{array}$ \\
\hline LFI economies & $\begin{array}{l}6.40 \\
(0.56)\end{array}$ & $\begin{array}{c}4.85 \\
(0.55)\end{array}$ & $\begin{array}{c}6.50 \\
(0.93)\end{array}$ & $\begin{array}{c}6.34 \\
(0.91)\end{array}$ & $\begin{array}{c}4.79 \\
(0.82)\end{array}$ \\
\hline \multicolumn{6}{|c|}{$\begin{array}{l}\text { Ratio of Total Consumption }(C+G) \\
\text { to Income }(\mathbf{Q})\end{array}$} \\
\hline Industrial countries & $\begin{array}{l}0.67 \\
(0.02)\end{array}$ & $\begin{array}{c}0.75 \\
(0.09)\end{array}$ & $\begin{array}{c}0.56 \\
(0.03)\end{array}$ & $\begin{array}{c}0.61 \\
(0.06)\end{array}$ & $\begin{array}{c}0.58 \\
(0.06)\end{array}$ \\
\hline MFI economies & $\begin{array}{l}0.81 \\
(0.07)\end{array}$ & $\begin{array}{c}0.92 \\
(0.13)\end{array}$ & $\begin{array}{c}0.74 \\
(0.12)\end{array}$ & $\begin{array}{c}0.76 \\
(0.11)\end{array}$ & $\begin{array}{c}0.92 \\
(0.04)\end{array}$ \\
\hline LFI economies & $\begin{array}{l}0.80 \\
(0.08)\end{array}$ & $\begin{array}{c}0.95 \\
(0.06)\end{array}$ & $\begin{array}{c}0.68 \\
(0.10)\end{array}$ & $\begin{array}{c}0.82 \\
(0.51)\end{array}$ & $\begin{array}{c}0.84 \\
(0.14)\end{array}$ \\
\hline
\end{tabular}

Notes: From the bottom panel, the ratio of total consumption growth volatility to that of income growth volatility is first computed separately for each country. The reported numbers are the within-group medians of those ratios. (Note that this is not the same as the ratio of the median of consumption growth volatility to the median of income growth volatility.) Standard errors are reported in parentheses. 


\section{Appendix I. The Effects of Different Types of Capital Flows on Growth}

The cumulative evidence from the literature does not offer a clear-cut and robust support for the notion that capital flows generically provides a quantitatively big boost to economic growth. However, there have been several studies that suggest that different types of capital flows may have different effects.

Using data for the 1980s, De Mello (1999) reports evidence that FDI flows appear to promote economic growth in developing as well as OECD countries. Borenzstein, De Gregorio, and Lee (1998) find that the positive effect of FDI can be detected when the recipient countries have a sufficiently high level of human capital.

FDI and other types of capital flows into developing countries started to pick up momentum in the 1990s, making it highly desirable to look at the evidence based on more recent data. Reisen and Soto (2001) examine six types of capital flows: foreign direct investment, portfolio equity flows, portfolio bond flows, long-term bank credits, short term bank credits and official flows. They employ a dynamic panel regression framework to deal with potential endogeneity and missing variable problems and cover 44 countries over the period 1986-97. Of the six types of capital flows, only two, namely FDI and portfolio equity flows, are positively associated with subsequent economic growth rates.

Other studies have looked into the effects of different types of capital flows on domestic investment (and hence indirectly on growth). Bosworth and Collins (1999) analyzed such relationships using data covering 1979-95, focusing on variations within countries over time rather than variations across countries. These authors first removed the country means from the data, and then regressed investment and savings shares on various forms of capital inflows (relative to GDP). They found that more FDI and bank lending are positively associated with increases in domestic investment. In contrast, the association between portfolio capital inflows and domestic investment, while positive, is not statistically significant. These authors made an attempt to deal with the possibility that capital flows are endogenous, meaning that capital flows and domestic investment can both be determined simultaneously by a common third factor.

The World Bank's report on Global Development Finance (2001) replicated the Bosworth-Collins study using a data set with more countries and a longer time period (1972-98). It found that the association between FDI (or other long term capital inflows or bank lending) and domestic investment is stronger than between short-term debt and domestic investment. The association between portfolio capital and domestic investment is not statistically significant.

To summarize, across different recent studies surveyed here, FDI is one form of capital inflows that tends to be found positively associated with domestic investment and domestic growth in a relatively consistent manner. Other forms of capital inflows could also have a positive relationship, but their effects tend to be less robust or less strong. 


\section{Appendix II. Do Financial and Trade Integration Have Different Effects on Economic Development? Evidence from Life Expectancy and Infant Mortality}

As an alternative to examining the effect of openness on economic growth, this appendix asks: Do trade and financial openness help to raise life expectancy and reduce infant mortality in developing countries? Are their effects different?

There are three motivations for studying these questions (see Wei and Wu (2002b)). First, as life expectancy and infant mortality are important dimensions of a society's well-being, they are interesting objects to look at in their own right. Second, data on income level or growth come from national accounts. So all studies on economic growth have to make use of variations of the similar data sources. In comparison, vital statistics come from an entirely different data source (i.e., birth and death records) and are typically collected by different government agencies. Therefore, they offer an independent and complementary check on the effect of openness on the livelihood of people. Third, to compare income levels or growth rates across countries, it is necessary to make certain purchasing power parity (PPP) adjustments to nominal income. However, existing PPP adjustments may not be reliable (Deaton (2001)). In contrast, the definitions of life and death are consistent across countries, so there is a higher degree of comparability than the data on poverty, income or income distribution.

Data on 79 developing countries over the period 1962-97 are examined. This data set covers all developing countries for which the relevant data exist and for which changes in infant mortality and life expectancy are not dominated by large-scale wars, genocides, famines, or major outbursts of AIDS epidemics. Panel regressions with country fixed effects as well as dynamic panel regressions are employed to account for other factors that may affect health and to account for possible endogeneity of the openness variables.

The results, summarized in Figure II.1, suggest that the effects of trade and financial openness are different. There is no positive and robust association across developing countries between faster increase in financial integration and faster improvement in a society's health. By comparison, there are several pieces of evidence suggesting that higher trade integration is associated with a faster increase in life expectancy and a faster reduction in infant mortality. For example, an 11 percentage point reduction in the average statutory tariff rate-approximately equal to one standard deviation of the change in the statutory tariff rate over the 1962-97 period-is associated with between 3 to 6 less infants dying per thousand live births, even after controlling for the effects of changes in per capita income, average female education and other factors. 
Figure II.1. Differential Effects of Financial and Trade Integration

on Improvements in Health

A lower trade barrier is associated with a longer life expectancy, but higher financial integration is not.

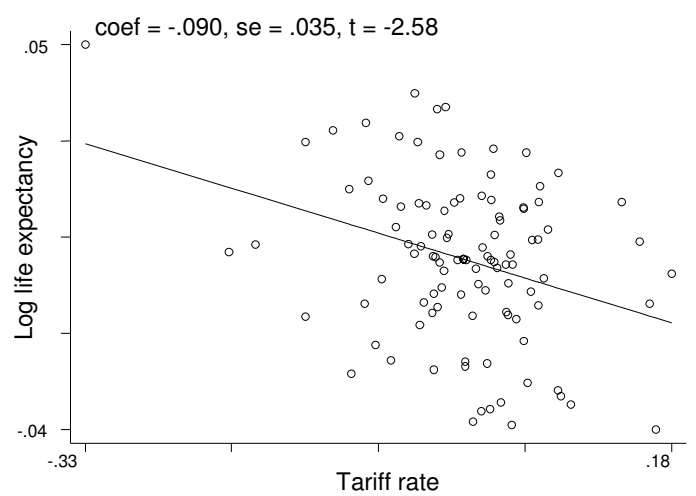

Note: conditional on income per capita, years of schooling, physicians per 1000 people, democracy, and country fixed effects.

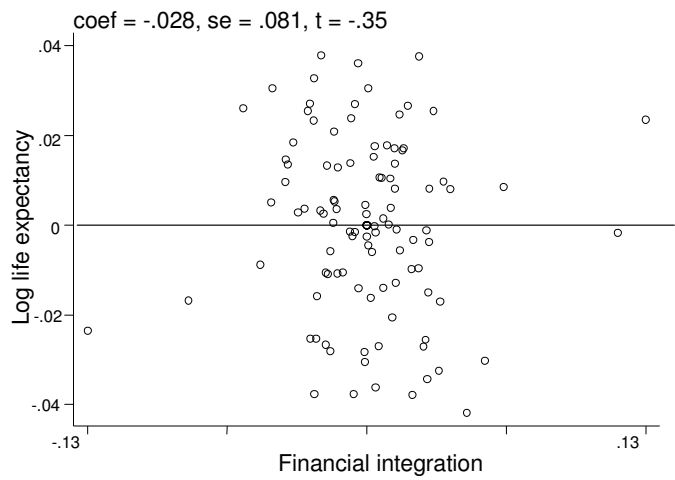

Note: conditional on tariff rate, income per capita, years of schooling, physicians per 1000 people, democracy, and country fixed effects.

A lower trade barrier is associated with lower infant mortality, but a rise in financial integration is not.

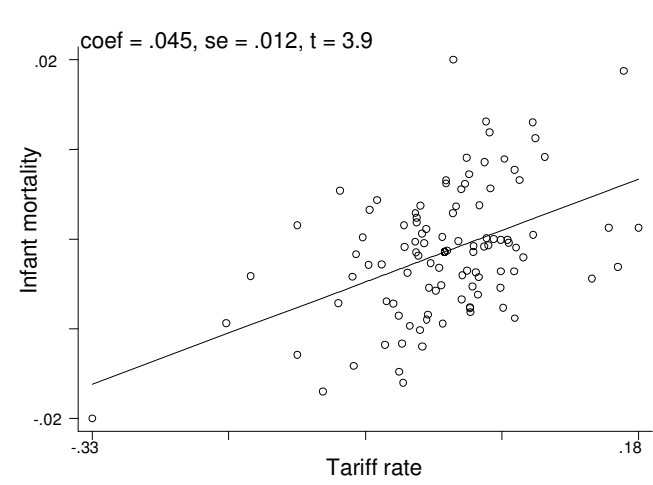

Note: conditional on income per capita, years of schooling, physicians per 1000 people, democracy, and country fixed effects.

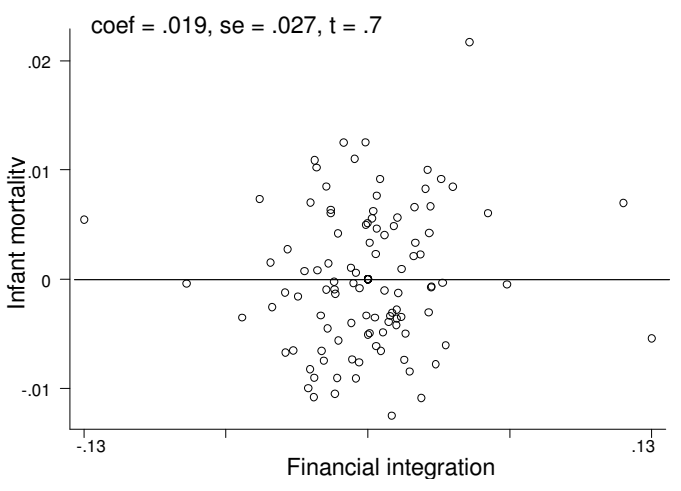

Note: conditional on tariff rate, income per capita, years of schooling, physicians per 1000 people, democracy, and country fixed effects.

Notes: On the vertical axises in the figures in the first row is log life expectancy at birth (in years). On the vertical axises in the figures in the second row is infant mortality, defined as the number of infants who die before reaching the first birthday per 1000 live births. Tariff rate refers to average statutory tariff rate. Financial integration is measured by (gross private capital inflows + gross private capital outflows) / GDP.

Source: These calculations are based on Wei and Wu (2002b). 


\section{Appendix III. The Effects of Globalization on Volatility: A Review of the Empirical Evidence}

Unlike the rich empirical literature focusing on the impact of financial openness on economic growth, there are only a limited number of studies analyzing the links between openness and macroeconomic volatility. Moreover, existing studies have generally been unable to document a clear empirical link between openness and macroeconomic volatility. Razin and Rose (1994) study the impact of trade and financial openness on the volatility of output, consumption, and investment for a sample of 138 countries over the period 1950-88. They find no significant empirical link between openness and the volatility of these variables.

Easterly, Islam, and Stiglitz (2001) explore the sources of output volatility using data for a sample of 74 countries over the period 1960-97. They find that a higher level of development of the domestic financial sector is associated with lower volatility. On the other hand, an increase in the degree of trade openness leads to an increase in the volatility of output, especially in developing countries. Their results indicate that neither financial openness nor the volatility of capital flows has a significant impact on output volatility.

Buch, Dopke, and Pierdzioch (2002) use data for 25 OECD countries to examine the link between financial openness and output volatility. They report that there is no consistent empirical relationship between financial openness and the volatility of output. Gavin and Hausmann (1996) study the sources of output volatility in developing countries over the period 1970-92. They find that there is a significant positive association between the volatility of capital flows and output volatility. O'Donnell (2001) examines the effect of financial integration on the volatility of output growth over the period 1971-94 using data for 93 countries. He finds that a higher degree of financial integration is associated with lower (higher) output volatility in OECD (non-OECD) countries. His results also suggest that countries with more developed financial sectors are able to reduce output volatility through financial integration.

Bekaert, Harvey, and Lundblad (2002) examine the impact of equity market liberalization on the volatility of output and consumption during 1980-2000. They find that, following equity market liberalizations, there is a significant decline in both output and consumption volatility. Capital account openness reduces the volatility of output and consumption, but its impact is smaller than that of equity market liberalization. However, they also report that capital account openness increases the volatility of output and consumption in emerging market countries. The September 2002 WEO provides some evidence indicating that financial openness is associated with lower output volatility in developing countries. 


\section{Appendix IV. Calculating the Potential Welfare Gains from International Risk Sharing}

International financial integration could result in potentially large welfare gains as it allows domestic residents, firms, and countries to smooth fluctuations in their consumption/revenue by diversifying away country-specific risks. For example, during recessions, countries can borrow from international markets and mitigate the adverse impact of declines in aggregate output on consumption and investment. During expansions, they can lend to other countries and/or pay back the loans they borrow during the recessions. Domestic residents and firms can also utilize international financial markets for consumption smoothing and receive large welfare benefits as these markets significantly expand the set of available financial instruments for international risk sharing purposes. Firms can invest in plants abroad to protect themselves against shocks associated with domestic cost or productivity changes.

Developing countries, in particular, can obtain large welfare gains through international risk sharing considering the highly volatile nature of income and consumption dynamics in these countries. Generally speaking, the scope for benefiting from international risk sharing tends to be large when a country's consumption growth is volatile, positively correlated with domestic output growth, and not highly correlated with world consumption. Recent empirical studies suggest that these features tend to characterize most developing countries. This is particularly the case, on average for LFI economies, somewhat less so for MFI economies, and still less so for advanced countries.

The potential welfare gains from international risk sharing and the consequent reduction in the volatility of consumption can be calculated using a simple model (see below for details). ${ }^{51}$ In brief, the model compares two scenarios. The first one has no additional risk sharing (relative to what is already implied by observed consumption behavior) while, in the second one, there is perfect risk-sharing so that each country consumes a (constant) fraction of total world consumption. Since total world consumption tends to be less volatile than the consumption of individual countries, the second scenario results in smoother national consumption patterns. The model can be used to generate quantitative estimates of the consumption-equivalent increase in welfare resulting from such reductions in consumption volatility.

Figure IV.1 reports the median gains (in terms of per capita consumption) for each group of economies. The gains are generally inversely proportional to the current degree of financial integration with the world economy. Highly volatile consumption fluctuations faced by LFI economies implies that the benefits to financial integration and consequent reductions in consumption volatility would be very large for these economies. On average, these benefits would have the same effect as about a 6 percent permanent increase in the level

\footnotetext{
${ }^{51}$ The calculations closely follow the methodology employed in van Wincoop $(1994,1999)$.
} 
Figure IV.1. Welfare Gains from International Risk Sharing

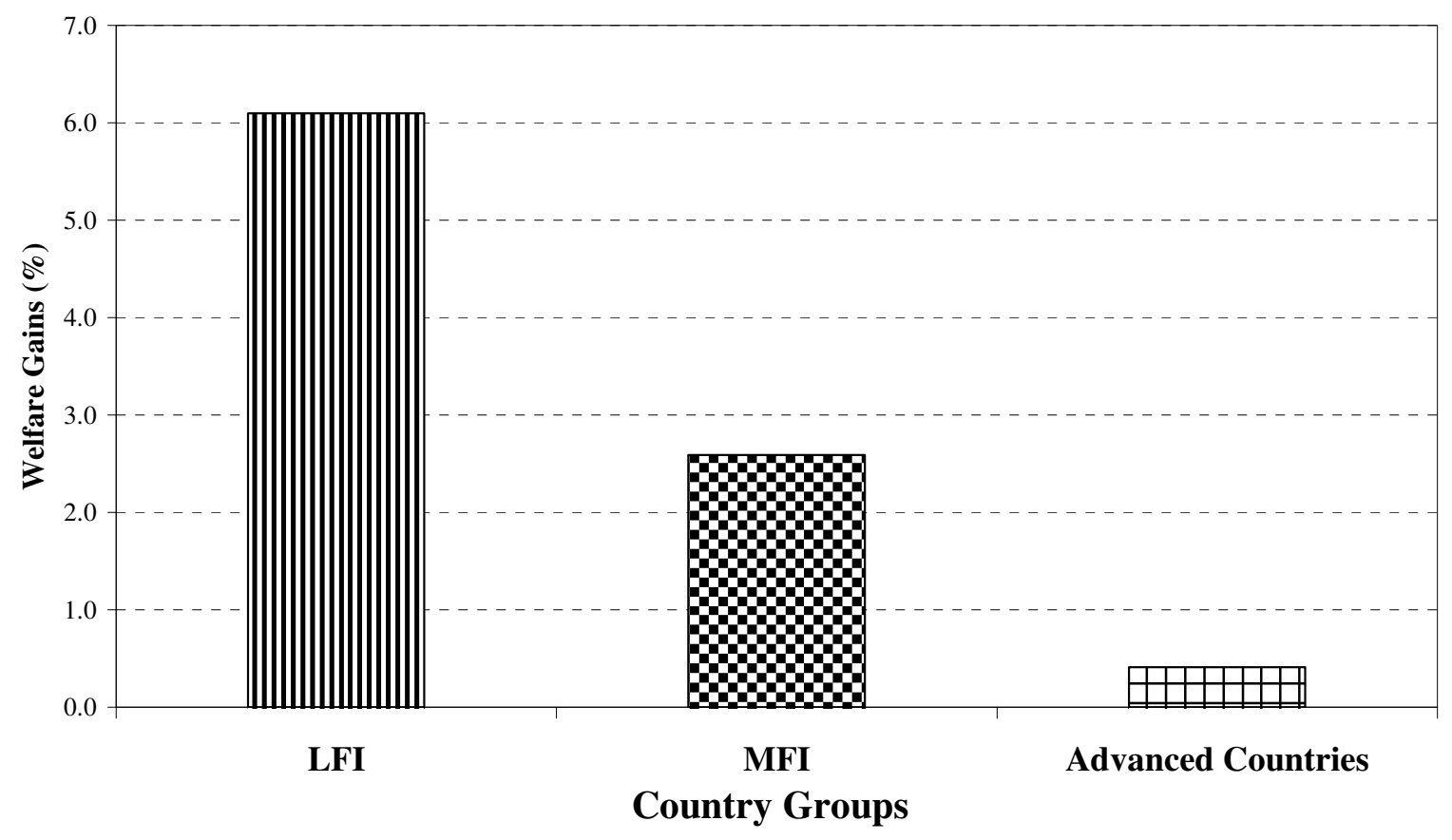

Note: Welfare gains measured in percent of consumption. 
of per capita consumption. ${ }^{52}$ Even for MFI economies, the potential gains from further international risk-sharing are quite large.

\section{Methodology}

This subsection briefly explains the methodology underlying the welfare gain calculations summarized above. During the past decade, a growing body of literature has examined the welfare implications of international risk sharing. While some studies focus on the welfare gains based upon consumption series, some others examine the gains from risk sharing using stock returns data in this literature. In these studies, a consumer/investor is able to increase her current welfare because she is able to reduce the volatility of her marginal utility of consumption/wealth over her life time by pooling country specific risk associated with the fluctuations in her consumption/wealth.

Most studies in this literature employ dynamic representative agent models and consider a variety of stochastic processes for consumption series. ${ }^{53}$ The standard approach in these studies involves determining consumption allocations under two environments. Under the first environment, there is no risk sharing and domestic consumption is equal to domestic output. Under the second environment, there is often perfect consumption risk sharing as countries are able to diversify away all country specific risk associated with fluctuations in domestic consumption. ${ }^{54}$ Moving from the first environment to the second one, the volatility of consumption in each country could go down, the pricing of the consumption streams of countries might change, and the cross-country correlations of consumption series could increase. The resulting welfare gains are associated with reductions in the volatility of consumption and/or changes in the pricing of the consumption series. The welfare gain calculations generate a welfare estimate which is equal to the permanent relative increase in the expected level of consumption that would lead to the same welfare under international risk sharing.

As with several earlier studies, standard practice is followed here and consumption allocations under two environments are computed using a simple representative agent model economy. In particular, the welfare gain calculations here closely follow the methodology employed in van Wincoop $(1994,1999)$. In the model economy, there are $\mathrm{N}$ countries which can trade in claims on their endowment streams when there is perfect consumption risk sharing. Residents in each country have the same preferences and expected utility is equal to

\footnotetext{
${ }^{52}$ While the actual welfare estimates depend on the parameterization of the model, the general flavor of these results is unaffected by the choice of parameter values.

${ }^{53}$ While the literature based upon consumption/output series employs general equilibrium models with utility depends on the level of consumption, the literature based upon equity returns generally uses partial equilibrium models with utility directly depends upon wealth. The approach using equity returns data involves devising an optimum portfolio composed of domestic and foreign stocks that minimize variance and maximize returns.

${ }^{54}$ Some studies also consider the welfare implications of imperfect risk sharing arrangements involving transactions with risk-free bonds (see Kim and Kim (2003) and Kim, Kim, and Levin (2003)).
} 


$$
U_{i}=E \int_{0}^{H} e^{-\beta t} \frac{\left(c_{i t}\right)^{1-\gamma}}{1-\gamma} d t
$$

where $H$ is the horizon (number of years), $\gamma$ denotes the rate of relative risk aversion, $c_{i t}$ is aggregate consumption by residents of country $i .^{55} y_{i t}$ represents the endowment and follows a random walk with drift:

$$
d y_{i t}=\mu y_{i t} d t+\sigma y_{i t} d \eta_{i}
$$

where $\eta_{i}$ is a standard Brownian motion. $\rho=d \eta_{i} d \eta_{k}(i \neq k)$ represents the correlation between the innovations of endowment growth across two different countries.

In the first environment, there is no additional risk sharing relative to what is already implied by observed consumption behavior and domestic consumption is equal to domestic output, $c_{i t}=y_{i t}$. This consumption allocation generates the following expected utility

$$
U_{i}=\frac{1-e^{-v T}}{v} \frac{\left(c_{i 0}\right)^{1-\gamma}}{1-\gamma}
$$

where $v=\beta+(\gamma-1)\left(\mu-0.5 \gamma \sigma^{2}\right)$.

In the second environment, there is perfect consumption risk sharing as countries are able to diversify away all country specific risk associated with domestic consumption. This implies that consumption in each country is equal to the per capita world endowment, which is denoted by $y^{W}$. Aggregate consumption of a representative country in this case follows approximately a random walk process with variance $\sigma_{W}^{2}=\sigma^{2}((1 / N)+(1-1 / N) \rho)$ (see Lewis (2000)). The measure of the welfare gain is the permanent percentage increase in the expected level of consumption which produces an equivalent improvement in welfare. The approximate welfare gain for the representative country is computed using the following formula

$$
\text { Welfare Gain } \approx-\frac{0.5 \gamma d \sigma^{2}}{r-\bar{\mu}}\left[1-H(r-\bar{\mu}) \frac{e^{-H(r-\bar{\mu})}}{1-e^{-H(r-\bar{\mu})}}\right]
$$

\footnotetext{
${ }^{55}$ It is assumed that all consumption goods are tradable. It is possible to consider a utility formulation with separable tradable and non-tradable consumption goods. However, sharing of risk associated with the fluctuations in non-tradables consumption is not possible and our dataset does not allow us to make a distinction between tradable and non-tradable consumption.
} 
where $\bar{\mu}=\mu-0.5 \gamma \sigma^{2}$ denotes the risk adjusted growth rate, $r=\beta+\gamma \bar{\mu}$ represents the risk free interest rate, and $d \sigma^{2}=\sigma_{W}^{2}-\sigma^{2}$ is the change in the variance of consumption growth.

The main parameters of the model are also taken from van Wincoop (1999). In particular, the risk-free real interest rate is assumed to be 0.85 percent and the coefficient of relative riskaversion is set at $3 .^{56}$ For each country, the mean growth rate and variance of per capita domestic consumption, and the correlation between the per capita domestic consumption growth and the world consumption growth are estimated and these values are used in the calculations. Since the dataset employed covers the 1970-97 period, these gains correspond to a horizon of 28 years. A decrease in the risk free rate translates into larger welfare gains while a decrease in the risk aversion coefficient is associated with smaller gains. The welfare gains get smaller with the correlation between domestic consumption and the world consumption while they tend to increase in the volatility of consumption series.

The welfare gains reported in the main text of this paper are consistent with the estimates found in some recent studies. While some of these studies report relatively small gains, a majority of them finds that gains from risk sharing are quite large, especially for developing countries as Table IV.1 displays. van Wincoop (1994) provides a detailed explanation of why various studies report different results. There are four major parameters affecting the magnitude of welfare gains in these studies: (1) the volatility of domestic output; (2) the rate of relative risk aversion; (3) the risk-adjusted growth rate, and (4) the risk free interest rate. It is easy to understand why some of the studies produce relatively low welfare gains: In some studies (Cole and Obstfeld (1991) and Obstfeld (1994a)) the risk-free rate is quite high. Some studies assume certain stationary processes for consumption or shock series, which generate low welfare gains because of the low persistence or volatility associated with these processes (Tesar (1995) and Mendoza (1995)).

Some studies use the data of advanced countries and find large welfare gains through international risk sharing. ${ }^{57}$ For example, van Wincoop (1999) finds that for the OECD countries the potential welfare gains from international risk sharing are between 1.1 percent to 3.5 percent. Several recent studies consider the implications of international risk sharing for developing

\footnotetext{
${ }^{56}$ Since these approximate calculations ignore the pricing problem of international claims, they do not include the welfare changes associated with the pricing of countries' endowment streams. In countries with highly volatile consumption fluctuations, the welfare losses from price changes can be quite large. However, as the volatility of consumption increases, the welfare gain from risk sharing rapidly rises and outweighs the losses due to the pricing of consumption streams. van Wincoop (1994) provides an extensive discussion of the gains associated with these price changes using the data of the OECD countries.

${ }^{57}$ Calculations of the gains from international risk sharing based upon stock returns produce much larger welfare gains estimates than those based upon international consumption data do. Lewis (1999) examines this issue and finds that the major differences are due to the much higher volatility of stock returns and the implied intertemporal substitution in marginal utility. Lewis (1999) reports that the gains to international risk sharing based upon stock based upon stock returns are quite large, around 10 to 50 percent. Le Baron (2002) claims that these gains got smaller during the past 15 years.
} 
countries. Athanasoulis and van Wincoop (2000) calculate the estimates of the degree of uncertainty associated with the growth potential of an economy at various horizons. They find that the welfare gain from sharing of risk associated with the growth uncertainty is around 6.5 percent using the data of 49 developed and developing countries. Obstfeld (1995) finds that elimination of consumption variability through risk sharing can result in much larger welfare gains in developing countries and reports that these gains are between 0.54 percent and 5.31 percent for a selected group of developing economies. Pallage and Robe (2002) find that the welfare gains associated with smoothing consumption fluctuations are much larger in African countries than those in the United States, and depending on the parameterization of the model economy these gains can easily exceed 10 percent for several African countries. 
Table IV.1. Summary of Studies on Welfare Gains from International Risk Sharing

Study $\backslash$ Countries Studied

Welfare Gains

\section{Advanced Countries}

\begin{tabular}{ll}
\hline Lucas (1987) & Small \\
Cole and Obstfeld (1991) & Small \\
Backus, Kehoe, and Kydland (1992) & Small \\
Mendoza (1995) & Small \\
Tesar (1995) & Small \\
Kim, Kim, and Levine (2002) & Small \\
Obstfeld (1994a) & Large \\
van Wincoop (1994, 1996, 1999)) & Large \\
Pallage and Robe (2002b) & Large \\
Epaulard and Pommeret (2001) & Large \\
Lewis (1996) & Large \\
Shiller and Athanasoulis (2001) & Large \\
Auffret (2001) & Large \\
Kim and Kim (2002) & Large \\
\end{tabular}

\section{Advanced, MFI and LFI Countries}

\begin{tabular}{ll}
\hline Obstfeld (1994b, 1995) & Large \\
Pallage and Robe (2002a) & Large \\
Athanasoulis and van Wincoop (1999) & Large \\
De Ferranti et. al. (2000) & Large \\
Athanasoulis and Shiller (1995) & Large
\end{tabular}

Notes: "Small" refers to the studies which report welfare gains less than $0.5 \%$ and "Large" refers to the studies which report welfare gains larger than $0.5 \%$. 


\section{Data Appendix}

Unless indicated otherwise, the primary sources for the data used in this paper are the IMF's International Financial Statistics and the World Bank's World Development Indicators. The basic data sample comprises 76 countries-21 industrial and 55 developing. ${ }^{58}$

\section{Industrial countries}

Australia (AUS), Austria (AUT), Belgium (BEL), Canada (CAN), Denmark (DNK), Finland (FIN), France (FRA), Germany (DEU), Greece (GRC), Ireland (IRL), Italy (ITA), Japan (JPN), Netherlands (NLD), New Zealand (NZL), Norway (NOR), Portugal (PRT), Spain (ESP), Sweden (SWE), Switzerland (CHE), United Kingdom (GBR), and United States (USA).

\section{Developing countries}

These are grouped into More Financially Integrated (22) and Less Financially Integrated (33) countries.

MFIs

Argentina (ARG), Brazil (BRA), Chile (CHL), China (CHN), Colombia (COL), Egypt (EGY), Hong Kong (HKG), India (IND), Indonesia (IDN), Israel (ISR), Korea (KOR), Malaysia (MYS), Mexico (MEX), Morocco (MAR), Pakistan (PAK), Peru (PER), Philippines (PHL), Singapore (SGP), South Africa (ZAF), Thailand (THA), Turkey (TUR), and Venezuela (VEN).

\section{LFIs}

Algeria (DZA), Bangladesh (BGD), Benin (GEN), Bolivia (BOL), Botswana (BWA), Burkina Faso (BFA), Burundi (BDI), Cameron (CMR), Costa Rica (CRI), Cote d'Ivoire (CIV), Dominican Republic (DOM), Ecuador (ECU), El Salvador (SLV), Gabon (GAB), Ghana (GHA), Guatemala (GTM), Haiti (HTI), Honduras (HND), Jamaica (JAM), Kenya (KEN), Mauritius (MUS), Nicaragua (NIC), Niger (NER), Nigeria (NGA), Panama (PAN), Papua New Guinea (PNG), Paraguay (PRY), Senegal (SEN), Sri Lanka (LKA), Syrian Arab Republic (SYR), Togo (TGO), Tunisia (TUN), and Uruguay (URY).

\footnotetext{
${ }^{58}$ The following were excluded from the analysis: small countries (those with population below 1 million), transition economies, some oil producers, and other countries with incomplete or clearly unreliable data.
} 


\section{References}

Acemoglu, Daron, Simon Johnson, and James A. Robinson, 2001, "Reversal of Fortune:

Geography and Institutions in the Making of the Modern World Income Distribution,"

MIT Working Paper 01/38 (Cambridge, Massachusetts: MIT, Department of Economics).

Agénor, Pierre-Richard, 2002, "Macroeconomic Adjustment and the Poor: Analytical Issues and Cross-Country Evidence," World Bank Working Paper No. 2788 (Washington: World Bank).

— 2002b, "Business Cycles, Economic Crises, and the Poor: Testing for Asymmetric Effects," Journal of Policy Reform, Vol. 5, pp. 145-160.

_ , 2003, "Does Globalization Hurt the Poor?,” WB Working Paper (Washington: World Bank).

Aizenman, Joshua, 2002, "Volatility, Employment, and the Patterns of FDI in Emerging Markets,” NBER Working Paper No. 9397 (December).

Alesina, Alberto, Vittorio Grilli, and Gian Maria Milesi-Ferretti, 1994, "The Political Economy of Capital Controls," in Capital Mobility: The Impact on Consumption, Investment, and Growth, ed. by Leonardo Leiderman and Assaf Razin (Cambridge: Cambridge University Press for CEPR).

Arestis, Phillip, and Phillip Arestis, 2004, "Financial Liberalization and Poverty: Channels of Influence" The Levy Economics Institute Working Paper 411 (New York: The Levy Economics Institute).

Arteta, Carlos, Barry Eichengreen, and Charles Wyplosz, 2001, "On the Growth Effects of Capital Account Liberalization” (unpublished; Berkeley: University of California).

Athanasoulis, Stefano, and Robert Shiller, 2001, "World Income Components: Measuring and Exploiting Risk-Sharing Opportunities," American Economic Review, Vol. 91, No. 4, pp. 1031-54.

Athanasoulis, Stefano, and Eric van Wincoop, 2000, "Growth Uncertainty and Risksharing," Journal of Monetary Economics, 45, 2000, 477-505.

Attanasio, Orazio, and Gianluca Violante, 2000, "The Demographic Transition in Closed and Open Economies: A Tale of Two Regions," IADB Working Paper (Washington: InterAmerican Development Bank).

Auffret, Philippe, 2001, “An Alternative Unifying Measure of Welfare Gains from Risk Sharing,” World Bank Working Paper 2676 (Washington: World Bank, September). 
Backus, David K., Patrick J. Kehoe, and Finn E. Kydland, 1992, "International Real Business Cycles," Journal of Political Economy, Vol. 100, pp. 745-775.

Bakker, Bas and Bryan Chapple, 2002, "Advanced Country Experiences with Capital Account Liberalization,” IMF Occasional Paper No. 214 (Washington: International Monetary Fund).

Barrett, Christopher B., and David E. Sahn, 2001, "Food Policy in Crisis Management," Cornell University.

Baldacci, Emanuele, Luiz de Mello, and Gabriela Inchauste, 2002, "Financial Crises, Poverty, and Income Distribution," Finance and Development, Vol. 39, No. 2 (June), pp. 24-27.

Bartolini, Leonardo, and Allan Drazen, 1997a, "Capital-Account Liberalization as a Signal," American Economic Review, Vol. 87, No. 1 (March), pp. 138-54.

Bayoumi, Tamim, Giorgio Fazio, Manmohan Kumar and Ronald MacDonald, 2003, "Fatal Attraction: Unising Distance to Measure Contagion in Good Times As Well As Bad".

Bekaert, Geert, Campbell R. Harvey, and Christian Lundblad, 2001, "Does Financial Liberalization Spur Growth?” NBER Working Paper No. 8245 (Cambridge, Massachusetts: National Bureau of Economic Research).

— , 2001b, "Emerging Equity Markets and Economic Development," Journal of Development Economics, Vol. 66, pp. 465-504.

_ _ 2002, "Growth Volatility and Equity Market Liberalization," Working Paper, (Duke University).

—_, 2002b, "Does Financial Liberalization Spur Growth?” mimeo, Columbia University.

Berg, Andrew, and Anne O. Krueger, 2002, "Trade, Growth, and Poverty: A Selective Survey," presented at the Annual Bank Conference on Development Economics in April.

Bikhchandani, Sushil, and Sunil Sharma, 2000, "Herd Behavior in Financial Markets," IMF Staff Papers, Vol. 47, No. 3 (Washington: International Monetary Fund).

Blankenau, William, M. Ayhan Kose, and Kei-Mu Yi, 2001, "Can World Real Interest Rates Explain Business Cycles in a Small Open Economy?," Journal of Economic Dynamics and Control, Vol. 25. pp. 867-889.

Bordo, Michael, and Barry Eichengreen, 2002, "Crises Now and Then: What Lessons from the Last Era of Financial Globalization," NBER Working Paper 8716 (Cambridge, Massachusetts: National Bureau of Economic Research). 
Borensztein, Eduardo, José De Gregorio, and Jong-Wha Lee, 1998, "How Does Foreign Direct Investment Affect Growth?” Journal of International Economics, Vol. 45 (June), pp. $115-35$.

Bosworth, Barry, and Susan Collins, 1999, "Capital Flows to Developing Economies: Implications for Saving and Investment," Brookings Paper on Economic Activity, Vol. 1 (Washington: Brookings Institution).

Boyer, Brian H., Michael S. Gibson, and Mico Loretan, 1999, "Pitfalls in Tests for Changes in Correlations." Federal Reserve Board, IFS Discussion Paper No. 597R.

Brainard, William C. and Richard N. Cooper (1968), "Uncertainty and Diversification of International Trade," Food Research Institute Studies in Agricultural Economics, Trade, and Development Vol. 8, pp. 257-285.

Buch, Claudia M., Jörg Döpke, and Christian Pierdzioch, 2002, "Financial Openness and Business Cycle Volatility,” Working Paper, Kiel Institute for World Economics.

Calvo, Guillermo, Leonardo Leiderman, and Carmen Reinhart, 1993, "Capital Inflows and Real Exchange Rate Appreciation in Latin America: The Role of External Factors," (with G. Calvo and L. Leiderman), Staff Papers, International Monetary Fund, Vol. 40 (March), pp. 108-151.

— York: St. Martin's Press; London: Macmillan Press).

— and Dollarization," Finance and Development, Vol. 36 (September), pp. 13-15.

—_ 2000, "When Capital Inflows Come to a Sudden Stop: Consequences and Policy Options" in Reforming the International Monetary and Financial System, ed. by P. Kenen and A. Swoboda, pp. 175-201 (Washington: International Monetary Fund).

— 2002, "Fear of Floating," Quarterly Journal of Economics, Vol. 117, No. 2 (May), pp. 379-408.

Caprio, Gerard, and Patrick Honohan, 1999, "Restoring Banking Stability: Beyond Supervised Capital Requirements," Journal of Economic Perspectives, Vol. 13, No. 4 (Fall), pp. 4364.

Carlson, Mark A., and Leonardo Hernandez, 2002, "Determinants and Repercussions of the Composition of Capital Inflows," IMF Working Paper 02/86 (Washington: International Monetary Fund).

Chanda, Areendam, 2001, “The Influence of Capital Controls on Long Run Growth: Where and How Much?" Working Paper, North Carolina State University. 
Cole, Harold L., and Maurice Obstfeld, 1991, "Commodity Trade and International Risksharing: How Much do Financial Markets Matter?," Journal of Monetary Economics, Vol. 28, pp. 3-24.

Corsetti, Giancarlo, Marcello Pericoli, and Massimo Sbracia, 2002, "Some Contagion, Some Interdependence: More Pitfalls in Tests of Financial Contagion," CEPR Discussion Paper, No. 3310 (April), pp. 1-28.

Deaton, Angus, 2001, "Counting the World's Poor: Problems and Possible Solutions," World Bank Research Observer, Vol. 16, No. 2 (Fall), pp. 125-47.

Dellas, Harris, and Martin K. Hess, 2002, "Financial Development and the Sensitivity of Stock Markets to External Influences," Review of International Economics, Vol. 10, No. 3 (August), pp. 525-38.

David de Ferranti, Guillermo E. Perry, Indermit S. Gill, and Luis Servén, 2000, Securing Our Future in a Global Economy, World Bank.

De Mello, Luiz, 1999, "Foreign Direct Investment-Led Growth: Evidence from Time Series and Panel Date," Oxford Economic Papers, Vol. 51, No. 1 (January), pp. 133-51.

Detragiache, Enrica and Spilimbergo, Antonio, 2002, "Crisis and Liquidity—Evidence and Interpretation,” IMF Working Papers 01/2 (Washington: International Monetary Fund).

Dollar, David, 2001, “Globalization, Inequality, and Poverty since 1980," Development Research Group WB Working Paper, (Washington: World Bank)

Duygan, Burcu, 2004, "Comsumption Patterns During Financial Crises: An International Comparison," Working Paper (Florence: European University Institute)

Easterly, William, R. Islam, and Joseph E. Stiglitz, 2001, "Shaken and Stirred: Explaining Growth Volatility," Annual World Bank Conference on Development Economics, ed. by B. Pleskovic and N. Stern.

Easterly, William, and Ross Levine, 2001, "It's Not Factor Accumulation: Stylized Facts and Growth Models," World Bank Economic Review, Vol. 15, pp. 177-219.

Easterly, William, 2004, "Globalization, Poverty, and All That: Factor Endowment versus Productivity Views," NBER Globalization and Poverty Workshop, Sept. 2004 (New York, New York University).

Edison, Hali, and Frank Warnock, 2001, "A Simple Measure of the Intensity of Capital Controls," International Finance Discussion Paper No. 705 (Washington: Board of Governors of the Federal Reserve, August). 
Edison, Hali, Michael Klein, Luca Ricci, and Torsten Sløk, 2002, "Capital Account Liberalization and Economic Performance: A Review of the Literature," IMF Working Paper 02/120 (July), (Washington: International Monetary Fund).

Edison, Hali, Ross Levine, Luca Ricci, and Torsten Sløk, 2002, "International Financial Integration and Economic Growth," Journal of International Monetary and Finance, Vol. 21, pp. 749-76.

Edwards, Sebastian, 2001, "Capital Mobility and Economic Performance: Are Emerging Economies Different?” NBER Working Paper No. 8076 (Cambridge, Massachusetts: National Bureau of Economic Research).

Eichengreen, Barry J., Donald J. Mathieson, and Bankim Chadha, 1998, "Hedge Funds and Financial Market Dynamics," IMF Occasional Paper No. 166 (Washington: International Monetary Fund).

Epaulard, Anne, and Aude Pommeret, 2003, "Recursive Utility, Endogenous Growth, and the Welfare Cost of Volatility," Review of Economic Dynamics, forthcoming.

Fatás, Antonio,, and I. Mihov, 2004, “The Case for Restricting Fiscal Policy Discretion”, forthcoming Quarterly Journal of Economics.

Fischer, Stanley, 1998, "Capital Account Liberalization and the Role of the IMF," in "Should the IMF Pursue Capital-Account Convertibility?," Essays in International Finance, Department of Economics, Princeton University, Vol. 207, pp. 1-10.

Frankel, Jeffery, 1992, “Measuring International Capital Mobility: A Review,” American Economic Review, Vol. 82 (May), pp. 197-202.

Forbes, Kristin and Robert Rigobon, 2000, "No Contagion, Only Interdependence: Measuring Stock Market Comovements," Journal of Finance, Vol. 57, No. 5 (October), pp. 222361.

— 2001, "Measuring Contagion: Conceptual and Empirical Issues." in International Financial Contagion, ed. by S. Claessens and K. Forbes (Boston, MA: Kluwer Academic Publishers).

Frankel, Jeffery A., and Andrew K. Rose, 1996, "Currency Crashes in Emerging Markets: An Empirical Treatment," Journal of International Economics, Vol. 41 (3-4), (November), pp. 351-66.

Gavin, Michael, and Ricardo Hausmann, 1996, "Sources of Macroeconomic Volatility in Developing Economies," IADB Working Paper (Washington: Inter-American Development Bank). 
Glick, Reuven, and Kenneth Rogoff, 1995, “Global versus Country-Specific Productivity Shocks and the Current Account," Journal of Monetary Economics, Vol. 35 (February), pp. 15992.

Goldberg, Pinelopi K and Nina Pavcnik, 2004, "Trade, Inequality, and Poverty: What do We Know? Evidence from Recent Trade Liberalization Episodes in Developing Countries," NBER Working Paper 10593, (Cambridge, Massachusetts: National Bureau of Economic Research).

Gourinchas, Pierre-Olivier, and Olivier Jeanne, 2003, "The Elusive Gains from International Financial Integration," NBER Working Paper 9684, (Cambridge, Massachusetts: National Bureau of Economic Research).

Grilli, Vittorio, and Gian Maria Milesi-Ferretti, 1995, "Economic Effects and Structural Determinants of Capital Controls," Staff Papers, International Monetary Fund, Vol. 42 (September), pp. 517-51.

Grossman, Gene M., and Elhanan Helpman, 1991a, Innovation and Growth in the Global Economy, (Cambridge, Mass. and London: MIT Press).

— 1991b, "Trade, Knowledge Spillovers, and Growth," European Economic Review, Vol. 35, No. 2-3 (April), pp. 517-26.

Hall, Robert E., Charles I. Jones, 1999, "Why Do Some Countries Produce So Much More Output Per Worker Than Others?" Quarterly Journal of Economics, Vol. 114, No. 1 (February), pp. 83-116.

Hanson, Gordon, 2001, “Should Countries Promote Foreign Direct Investment?, G-24 Discussion Paper No. 9 (February).

Harrison, Ann, and H. Tang, 2004, "Liberalization of Trade: Why So Much Controversy?", Manuscript, University of California, Berkeley.

Hausmann, Ricardo, and Eduardo Fernandez-Arias, 2000, "Foreign Direct Investment: Good Cholesterol?" IADB Working Paper No. 417 (Washington: Inter-American Development Bank).

Henry, Peter, 2000, "Stock Market Liberalization, Economic Reform, and Emerging Market Equity Prices," Journal of Finance, Vol. 55 (April), pp. 529-64.

Hnatkovska, Viktoria, and Norman Loayza, November 2003, "Volatility and Growth," working paper, World Bank.

Imbs Jean, and Roman Wacziarg, 2003, (forthcoming) "Stages of Diversification," American Economic Review. 
International Monetary Fund, 2001, World Economic Outlook, October.

International Monetary Fund, 2002, World Economic Outlook, September.

Ishii, Shogo, Karl Habermeier, Bernard Laurens, John Leimone, Judit Vadasz, and Jorge Ivan Canales-Kriljenko, 2002, "Capital Account Liberalization and Financial Sector Stability," IMF Occasional Paper No. 211, (Washington: International Monetary Fund).

Kalemli-Ozcan, Sebnem, Bent E. Sørensen, and Oved Yosha, 2001, "Risk Sharing and Industrial Specialization: Regional and International Evidence," (unpublished).

Kaminsky, Graciela, and Carmen M. Reinhart, 1999, "The Twin Crises: The Causes of Banking and Balance-of-Payments Problems," American Economic Review, Vol. 89, No. 3 (June), pp. 473-500.

— 2001, "Bank Lending and Contagion: Evidence from the Asian Crisis," in Regional and Global Capital Flows: Macroeconomic Causes and Consequences, ed. by T. Ito, and A. Krueger (Chicago: University of Chicago Press for the NBER), pp. 73-99.

— , 2002, "The Center and Periphery: The Globalization of Financial Turmoil," NBER Working Paper W9479.

Kemp, Murray and Nissan Liviatan (1973), "Production and Trade Patterns Under Uncertainty," The Economic Record, Vol. 49, pp. 215-227.

Kim, Jinill, Sunghyun Henry Kim and Andrew Levin, 2003, "Patience, Persistence, and Welfare Costs of Incomplete Markets in Open Economies," Journal of International Economics, 61, pp. 385-96.

Kim, Jinill and Sunghyun Henry Kim, 2003, Spurious Welfare Reversals in International Business Cycle Models, Journal of International Economics 60, pp. 471-500..

Kim, Sunghyun Henry, M. Ayhan Kose, and Michael Plummer, 2001, "Understanding the Asian Contagion,” Asian Economic Journal, Vol. 15, No. 2, pp. 111-138.

Klein, Michael, and Giovanni Olivei, 2000, "Capital Account Liberalization, Financial Depth, and Economic Growth" (unpublished; Medford, Mass: Tufts University).

Kouparitsas, Michael A., 1996, "North-South Business Cycles," Working Paper, No. 96-9, Federal Reserve Bank of Chicago.

Kose, M. Ayhan, 2002, "Explaining Business Cycles in Small Open Economies: How Much Do World Prices Matter?,” Journal of International Economics, Vol. 56, pp. 299-327.

_ Macroeconomic Volatility," IMF Staff Papers, vol: 50, 119-142. 
— 2003b, "How Does Globalization Affect the Synchronization of Business Cycles?,", American Economic Review, vol: 93, 57-62.

— , 2004, "How Do Trade and Financial Integration Affect the Relationship between Growth and Volatility?" forthcoming IMF Working Paper (Washington: International Monetary Fund).

Kose, M. Ayhan, Christopher Otrok and Charles Whiteman, 2003, "International Business Cycles: World, Region, and Country Specific Factors," American Economic Review vol: 93, 1216-1239.

Kose, M. Ayhan, and Raymond Riezman, 2001, "Trade Shocks and Macroeconomic Fluctuations in Africa," Journal of Development Economics, Vol. 65, pp. 55-80.

Kraay, Aart, 1998, "In Search of the Macroeconomic Effect of Capital Account Liberalization," (unpublished; Washington: World Bank).

_, 2004 , "When is Growth Pro-Poor? Cross-Country Evidence," IMF Working Paper 04/47, (Washington: International Monetary Fund).

Krueger, Anne O., and Jungho Yoo, 2002, "Chaebol Capitalism and the Currency-Financial Crisis in Korea," in Preventing Currency Crises in Emerging Markets, ed. by Sebastian Edwards and Jeffrey Frankel, pp. 461-501 (Chicago: University of Chicago Press).

Kumar, Manmoham S., and Avinash Persaud, 2001, "Pure Contagion and Investors' Shifting Risk Appetite: Analytical Issues and Empirical Evidence," IMF Working Paper 01/134 (Washington: International Monetary Fund).

Labán, Raul. M., and Felipe B. Larrain, 1997, "What Determines Capital Inflows? An Empirical Analysis for Chile," Harvard Institute for International Development Discussion Paper No. 590 (June), pp. 1-24.

Lane, Philip R., and Giani Maria Milesi-Ferretti, 2001, "The External Wealth of Nations: Measures of Foreign Assets and Liabilities for Industrial and Developing Nations," Journal of International Economics, Vol. 55, pp. 263-94.

LeBaron, Blake, 2002, "Estimating the Feasible Economic Gains from International Portfolio Diversification, Working Paper, (Brandeis University).

Levine, Ross, 1996, "Foreign Banks, Financial Development, and Economic Growth," International Financial Markets: Harmonization versus Competition, pp. 224-54 (Washington: AEI Press).

Lewis, Karen K., 1996, "What Can Explain the Apparent Lack of International Consumption Risksharing?," Journal of Political Economy, Vol. 104, No. 2, pp. 267-297. 
- 1999, Trying to Explain Home Bias in Equities and Consumption, Journal of Economic Literature Vol. 37, No. 2, pp. 571-608.

— 2000 , Why Do Stocks and Consumption Imply Such Different Gains from International Risk sharing? Journal of International Economics, Vol. 52, No. 1, pp. 1-35.

Loungani, Prakash, Ashoka Mody and Assaf Razin, 2003, "The Global Disconnect: The Role of Transactional Distance and Scale Economies in Gravily Equations," IMF Working Paper (Washington: International Monetary Fund).

Lucas, Robert E., 1987, “Models of Business Cycles”, (Blackwell, Oxford).

Lustig, Nora, 2000, "Crises and the Poor: Socially Responsible Macroeconomics," IDB Sustainable Development Department Technical Papers Series (Washington: InterAmerican Development Bank).

Martin, Philippe, and C.A. Rogers, 2000, "Long-term Growth and Short-term Economic Instability”, European Economic Review, Vol 44, pp359-381.

Mathieson, Donald J., and Liliana Rojas-Suarez, 1993, "Liberalization of the Capital Account: Experiences and Issues." IMF Occasional Paper No. 103 (Washington: International Monetary Fund).

Mauro, Paolo, Nathan Sussman, and Yishay Yafeh, 2002, "Emerging Market Spreads: Then versus Now," Quarterly Journal of Economics, Vol. 117, No. 2, pp. 695-733.

Mendoza, Enrique, 1995, “The Terms of Trade, the Real Exchange Rate and Economic Fluctuations," International Economic Review, Vol. 36, pp. 101-137.

Mishkin, Frederic S., 1999, “Lessons from the Asian Crisis,” NBER Working Paper 7102 (April), (Cambridge, Massachusetts: National Bureau of Economic Research).

Mody, Ashoka, 2002, “Is FDI Integrating the World Economy?” IMF manuscript.

— 02/75 (Washington: International Monetary Fund).

Mody, Ashoka, and Mark P. Taylor, 2002, "International Capital Crunches: The Time Varying Role of Informational Asymmetries,” IMF Working Paper 02/34 (Washington: International Monetary Fund).

Obstfeld, Maurice, 1994a, "Evaluation Risky Consumption Paths: the Role of Intertemporal Substitutability,” European Economic Review, Vol. 38, pp. 1471-1486. 
1994b, “Are Industrial-Country Consumption Risks Globally Diversified?," in Capital Mobility: The Impact of Consumption, Investment and Growth, ed. by L.Leiderman, and A. Razin, , (Cambridge: Cambridge University Press), pp. 13-47.

— 1995, "International Capital Mobility in the 1990s", in Understanding Interdependence, ed. by P.B. Kenen, pp. 201-261, (Princeton: Princeton University Press).

— (Cambridge, Massachusetts, London, England: MIT Press).

— No. 8846 (Cambridge, Massachussets: National Bureau of Economic Research).

O’Donnell, Barry, 2001, "Financial Openness and Economic Performance” (unpublished; Dublin: Trinity College).

O’Rourke, Kevin, 2001, “Globalization and Inequality: Historical Trends," CEPR Discussion Paper No. 2865 (London: Centre for Economic Policy Research).

Pallage, Stephane, and Michel A. Robe, 2003a, "On the Welfare Cost of Economic Fluctuations in Developing Countries," International Economic Review, Vol. 44, No. 2 (May), pp. 677-98.

_ 2003b, “The States versus The States: On the Welfare Costs of Business Cycles in the U.S." UQAM and American University Working Paper (January).

Prasad, Eswar, Kenneth Rogoff, Shang-Jin Wei and M. Ayhan Kose, 2003, "The Effects of Financial Globalization on Developing Countries: Some Empirical Evidence, International Monetary Fund Occasional Paper 220. Washington: International Monetary Fund.

Quah, Danny, 1997, Empirics for growth and distribution: Stratification, polarization, and convergence clubs, Journal of Economic Growth, vol. 2, no. 1, pp. $27-59$

Quinn, Dennis P. 1997. "The Correlates of Change in International Financial Regulation" American Political Science Review 91(September):531-551.

Radelet, Steven and Jeffrey Sachs, 1998, "The East Asian Financial Crisis: Diagnosis, Remedies, Prospects," Brookings Papers on Economic Activity, Vol. 1, pp. 1-74.

Ramey, G., Ramey, V., 1995. "Cross-Country Evidence on the Link Between Volatility and Growth,” The American Economic Review, Vo. 85, No. 5, pp. 1138-1151

Ravallion, Martin, 2003, “The Debate on Globalization, Poverty and Inequality: Why Measurement Matters," WB Policy Research Working Paper No. 3038 (Washington: World Bank). 
Razin, Assaf, and Andrew K. Rose, 1994, "Business-Cycle Volatility and Openness: An Exploratory Cross-Sectional Analysis," in Capital Mobility: The Impact on Consumption, Investment, and Growth, ed. by Leonardo Leiderman and Assaf Razin, pp. 48-76 (Cambridge: University Press).

Reinhart, Carmen M., and Vincent R. Reinhart, 2001, "What Hurts Most? G-3 Exchange Rate or Interest Rate Volatility," NBER Working Paper No. 8535 (October).

Reinhart, Carmen M., 2002, "Credit Ratings, Default and Financial Crises: Evidence from Emerging Markets," World Bank Economic Review (forthcoming).

Reinhart.Carmen M. and Kenneth Rogoff, 2004a, The Modern History of Exchange Rate Arrangements: A Reinterpretation," Quarterly Journal of Economics 119(1):1-48, February 2004a.

Reinhart.Carmen M. and Kenneth Rogoff, 2004b, Serial Default And The "Paradox" Of Rich To Poor Capital Flows," American Economic Review 94(2), May, 52-58.

Reisen, Helmut, and Marcelo Soto, 2001, "Which Types of Capital Inflows Foster DevelopingCountry Growth?," International Finance, Vol. 4, No. 1 (Spring), pp. 1-14.

Rodrik, Dani, 1998, "Who Needs Capital-Account Convertibility?," Essays in International Finance, No. 207 (Princeton: Princeton University).

— Conference on Development Economics, 1999, pp. 59-90 (Washington: World Bank).

Rodriguez, Francisco, and Dani Rodrik, 2001, “Trade Policy and Economic Growth: A Skeptic's Guide to the Cross-National Evidence," in NBER Macroeconomics Annual 2000, ed. by Ben S. Bernanke and Kenneth Rogoff (Cambridge, Massachussets: The MIT Press).

Rogoff, Kenneth, 2002, "Rethinking Capital Controls: When Should We Keep an Open Mind?" Finance and Development, December, Vol. 39, No. 4, pp. 55-56.

Rogoff, Kenneth, Aasim M. Husain, Ashoka Mody, Robin J. Brooks, and Nienke Oomes, Evolution and Performance of Exchange Rates Regimes, International Monetary Fund Occasional Paper 229, 2004. Washington: International Monetary Fund.

Ruffin, Roy J., 1974, "Comparative Advantage under Uncertainty," Journal of International Economics, Vol. 4, No. 3 (August), pp. 261-73.

Sala-i-Martin, Xaiver, 2002, "The Disturbing "Rise" of World Income Inequality", NBER Working Paper 8904.

Senhadji, Abdelhak, 2000, "Sources of Economic Growth: An Extensive Growth Accounting Exercise," Staff Papers, International Monetary Fund, Vol. 47, No. 1, pp. 129-57. 
Shiller, Robert J. and S. Athanasoulis, 1995, "World Income Components: Measuring and Exploiting International Risk Sharing Opportunities,” NBER Working Paper No. 5095 (Cambridge, Massachussets: National Bureau of Economic Research).

Stulz, Rene, 1999a, "International Portfolio Flows and Security Markets," International Capital Flows, NBER Conference Report Series, pp. 257-93 (Chicago and London: University of Chicago Press).

— 1999b, "Globalization of Equity Markets and the Cost of Capital," NBER Working Paper 7021 (March).

Taylor, Mark P., and Lucio Sarno, 1999, "The Persistence of Capital Inflows and the Behaviour of Stock Prices in East Asia Emerging Markets: Some Empirical Evidence," CEPR Discussion Paper 2150 (May).

Tesar, Linda L., 1995, "Evaluating the Gain from International Risksharing," CarnegieRochester Conference Series on Public Policy, Vol. 42, pp. 95-143.

van Rijckeghem, Caroline, and Beatrice Weder, 2000, "Spillover Through Banking Centers-A Panel Data Analysis," IMF Working Paper 00/88 (Washington: International Monetary Fund).

van Wincoop, Eric, 1994, "Welfare Gains from International Risksharing," Journal of Monetary Economics, Vol. 34, pp. 175-200.

_ , 1996, "A Multi-Country Real Business Cycle Model with Heterogeneous Agents," Scandinavian Journal of Economics, Vol. 98, pp. 233-251.

Van Wincoop, Eric, 1999, "How Big are Potential Welfare Gains from International Risk Sharing?" Journal of International Economics, Vol. 47, No. 1, pp. 109-135.

Wei, Shang-Jin and Yi Wu, 2002a, "Negative Alchemy? Corruption, Composition of Capital Flows, and Currency Crises," in Preventing Currency Crises in Emerging Markets, ed. by Sebastian Edwards and Jeffrey Frankel (Chicago: University of Chicago Press), pp. 461501.

— , 2002b, (forthcoming) “The Life-and-Death Implications of Globalization," IMF Working Paper (Washington: International Monetary Fund).

—_ 2001, Globalization and Inequality: Evidence from Within China, NBER Working Paper 8611, November 2001.

Williamson, John, and Molly Mahar, 1998, "A Survey of Financial Liberalization," Essays in International Finance, No. 211 (Princeton: New Jersey, Princeton University Press).

World Bank, 2001, Global Development Finance (Washington: World Bank) 